Supporting Information for

\title{
Rational design of a reversible fluorescent probe for sensing sulfur dioxide/formaldehyde in living cells, zebrafish and living mice
}

\author{
Yanyan Ma, Yonghe Tang, Yuping Zhao, and Weiying Lin*
}

Institute of Fluorescent Probes for Biological Imaging, School of Chemistry and Chemical Engineering, School of Materials Science and Engineering, University of Jinan, Jinan, Shandong 250022,P.R. China. E-mail: weiyinglin2013@163.com 


\section{Table of Contents}

\section{Page}

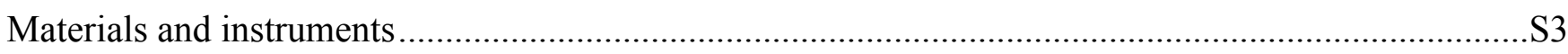

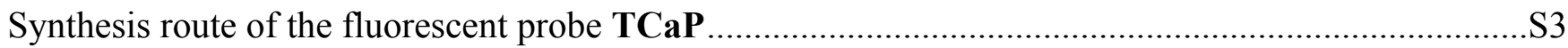

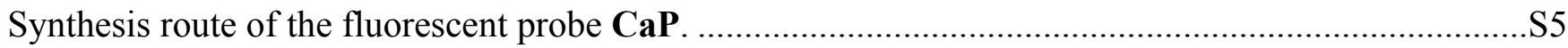

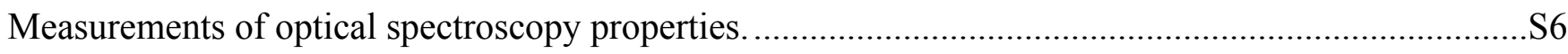

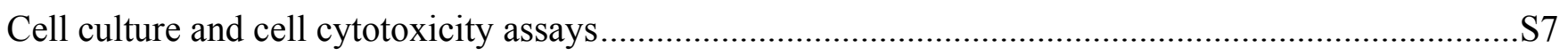

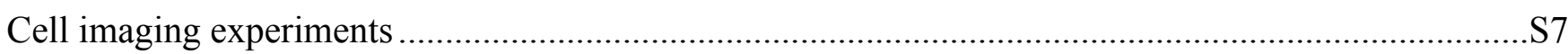

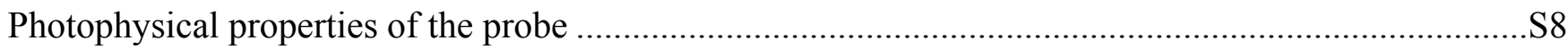

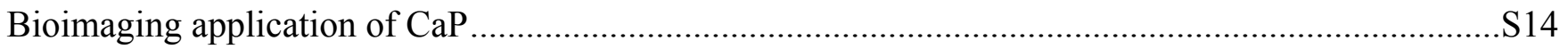

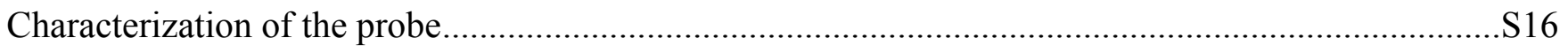

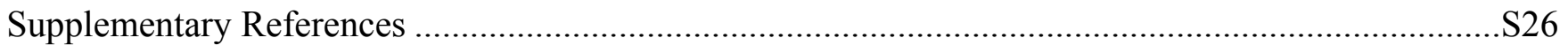

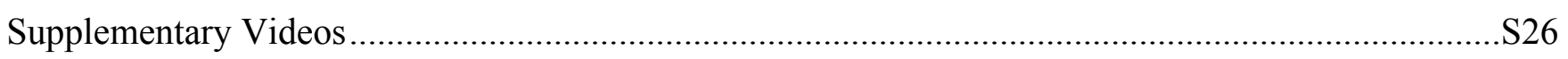




\section{Experimental Procedures}

\section{Materials and instruments}

Unless otherwise stated, ultrapure water was used in all experiments and all reagents were obtained from commercial suppliers

without further purification. Solvents were purified by standard methods prior to use. TLC analysis carried out on silica gel plates and column chromatography was conducted over silica gel (mesh 200-300), both of them were purchased from the Qingdao Ocean Chemicals. ${ }^{1} \mathrm{H}$ and ${ }^{13} \mathrm{C}$ NMR spectra were recorded on an AVANCE III 400 Nanobay (Bruker, $400 \mathrm{MHz}$ for ${ }^{1} \mathrm{H}, 100 \mathrm{MHz}$ for ${ }^{13} \mathrm{C}$ ) at room temperature, using DMSO- $d_{6}$ or $\mathrm{CDCl}_{3}$ as solvent and tetramethylsilane (TMS) as internal reference. High-resolution mass spectrometric (HRMS) analyses were measured on a Bruker apex-Ultra mass spectrometer (Bruker Daltonics Corp., USA) in electrospray ionization (ESI) mode. HRMS for response mechanism was collected using Agilent 6510 Q-TOF LC/MS for studying response mechanism. The $\mathrm{pH}$ measurements were performed with a Mettler-Toledo Delta $320 \mathrm{pH}$ meter. UV-vis absorption spectra were obtained on a Shimadzu UV-2700 spectrophotometer and fluorescence spectra were measured on a HITACHI F4600 fluorescence spectrophotometer. MTT was purchased from J\&K Scien-tific Ltd. Fluorescence imaging experiments were performed with Nikon A1MP confocal microscopy.

The reaction of $\mathrm{FA}$ and $\mathrm{HSO}_{3}^{-}$

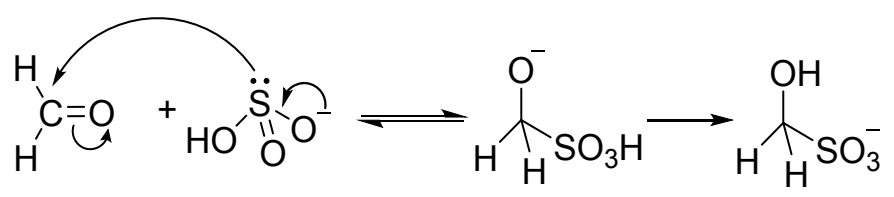

Scheme S1. The reaction of FA and $\mathrm{HSO}_{3}{ }^{-}$.

\section{Synthesis route of the fluorescent probe TCaP}




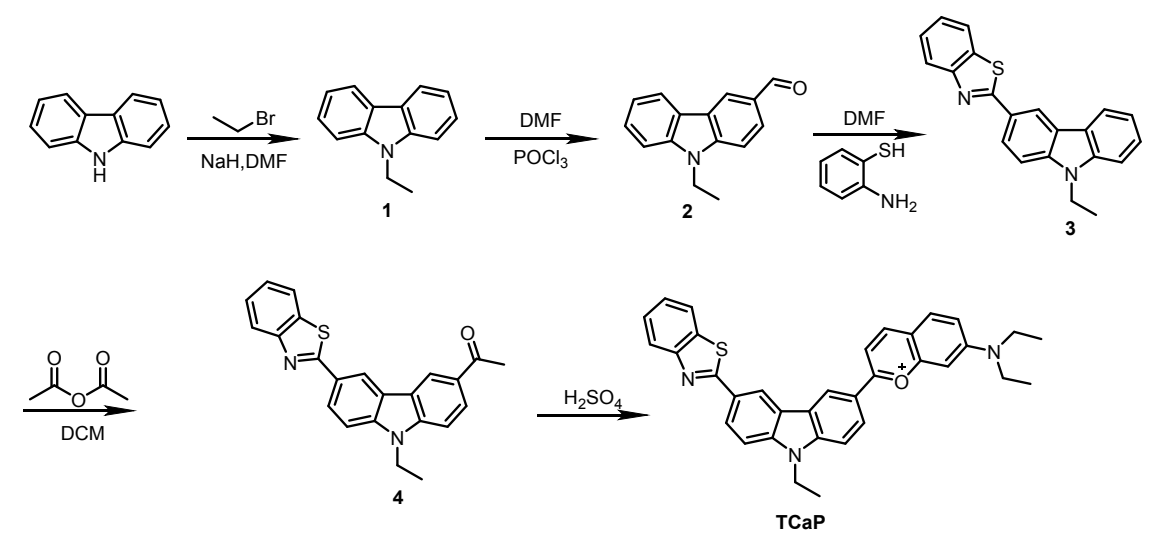

Scheme S2. Synthesis route of TCaP.

\section{Synthesis of compound 1}

$\mathrm{NaH}(60 \%$ in oil, $240 \mathrm{mg}, 6 \mathrm{mmol})$ was gradually added to a solution of carbazole $(1.67 \mathrm{~g}, 10 \mathrm{mmol})$ in DMF $(6 \mathrm{~mL})$ under stirring at room temperature for $1.5 \mathrm{~h}$. Then bromoethane $(5.4 \mathrm{~g}, 50 \mathrm{mmol})$ was added dropwise at room temperature. After $2 \mathrm{~h}$, the reaction mixture was added to ice water $(150 \mathrm{~mL})$, and the solution was extracted with ethyl acetate. The solvent was removed and dried under vacuum to afford white needle product (1.69 g, 87\%). Melting points: $65{ }^{\circ} \mathrm{C} .{ }^{1} \mathrm{H}$ NMR $\left(400 \mathrm{MHz}, \mathrm{DMSO}-d_{6}\right) \delta$ $8.16(\mathrm{~d}, J=8.0 \mathrm{~Hz}, 2 \mathrm{H}), 7.61(\mathrm{~d}, J=8.0 \mathrm{~Hz}, 2 \mathrm{H}), 7.46(\mathrm{~m}, 2 \mathrm{H}), 7.20(\mathrm{~m}, 2 \mathrm{H}), 4.44(\mathrm{q}, J=7.2 \mathrm{~Hz}, 2 \mathrm{H})$, $1.31(\mathrm{t}, J=7.2 \mathrm{~Hz}, 3 \mathrm{H})$.

\section{Synthesis of compound 2}

DMF $(1.80 \mathrm{~mL}, 25.3 \mathrm{mmol})$ was added into a three flask $(250 \mathrm{~mL})$, then $\mathrm{POCl}_{3}$ was added dropwise under ice bath and stirred until the white solid was obtained. The compound of $\mathbf{1}(5.00 \mathrm{~g}, 25 \mathrm{mmol})$ was dissolved in $\mathrm{CHCl}_{3}$ and then the mixture was added into the three flask. On completion of the addition, the ice bath was removed, and the solution was heated reflux with stirring overnight. After the reaction, the mixture was stopped heating and cooled to room temperature. The mixture was poured into a mixture of ice and water, stirred and then was adjusted $\mathrm{pH}$ value to 8 with $\mathrm{NaOH}$ solution and $\mathrm{NaHCO}_{3}$ solution. And then the mixture was extracted with $\mathrm{CH}_{2} \mathrm{Cl}_{2}$. The organic phase was dried with anhydrous $\mathrm{MgSO}_{4}$ and the solvent was dried. The residue was purified by column chromatography, and gave the light yellow solid (4.16 g, yield 83\%). Melting points: $79{ }^{\circ} \mathrm{C}{ }^{1} \mathrm{H}$ NMR (400 MHz, DMSO- $\left.d_{6}\right) \delta=10.07$ $(\mathrm{s}, 1 \mathrm{H}), 8.78(\mathrm{~d}, J=1.2 \mathrm{~Hz}, 1 \mathrm{H}), 8.31(\mathrm{~d}, J=7.6 \mathrm{~Hz}, 1 \mathrm{H}), 8.01\left(\mathrm{dd}, J_{1}=8.6 \mathrm{~Hz}, J_{2}=1.4 \mathrm{~Hz}, 1 \mathrm{H}\right), 7.80$ $(\mathrm{d}, J=8.4 \mathrm{~Hz}, 1 \mathrm{H}), 7.72(\mathrm{~d}, J=8.0 \mathrm{~Hz}, 1 \mathrm{H}), 7.56(\mathrm{~m}, 1 \mathrm{H}), 7.32(\mathrm{~m}, 1 \mathrm{H}), 4.53(\mathrm{q}, J=7.2 \mathrm{~Hz}, 2 \mathrm{H}), 1.35$ $(\mathrm{t}, J=7.0 \mathrm{~Hz}, 3 \mathrm{H})$.

\section{Synthesis of compound 3}


Compound 3 was synthesized according to the reported procedure. Briefly, to a solution of 2aminothiophenol (24 mmol, $2.52 \mathrm{~mL})$ and compound $2(12 \mathrm{mmol}, 2.78 \mathrm{~g})$ in DMF (50 mL), sodium metabisulfite $\left(\mathrm{Na}_{2} \mathrm{~S}_{2} \mathrm{O}_{5}, 2.40 \mathrm{~g}\right)$ was added and the reaction mixture was refluxed for $4 \mathrm{~h}$. After cooling, the resulting solution was added dropwise into water $(200 \mathrm{~mL})$. The precipitate was filtered, washed with water $(60 \mathrm{~mL})$ and dried to afford the crude product, which was further purified by recrystallization from methanol to give 3 as a dark yellow solid (2.55 g, yield 91\%). Melting points: $135^{\circ} \mathrm{C} .{ }^{1} \mathrm{H}$ NMR $\left(400 \mathrm{MHz}, \mathrm{DMSO}-d_{6}\right) \delta=8.93(\mathrm{~s}, 1 \mathrm{H}), 8.39(\mathrm{~d}, J=7.6 \mathrm{~Hz}, 1 \mathrm{H}), 8.21\left(\mathrm{dd}, J_{l}=8.6, J_{2}\right.$ $=1.8 \mathrm{~Hz}, 1 \mathrm{H}), 8.14(\mathrm{~m}, 1 \mathrm{H}), 8.05(\mathrm{~d}, J=7.6 \mathrm{~Hz}, 1 \mathrm{H}), 7.79(\mathrm{~d}, J=8.4 \mathrm{~Hz}, 1 \mathrm{H}), 7.69(\mathrm{~d}, J=8.0 \mathrm{~Hz}, 1 \mathrm{H})$, $7.55(\mathrm{~m}, 2 \mathrm{H}), 7.44(\mathrm{~m}, 1 \mathrm{H}), 7.28(\mathrm{~m}, 1 \mathrm{H}), 4.52$ (q, $J=7.1 \mathrm{~Hz}, 2 \mathrm{H}), 1.36(\mathrm{t}, J=7.2 \mathrm{~Hz}, 3 \mathrm{H})$.

\section{Synthesis of compound 4}

Compound 3 (2 g, $6 \mathrm{mmol})$ was added to $8 \mathrm{~mL} \mathrm{DCM}, \mathrm{AlCl}_{3}(1.6 \mathrm{~g}, 10 \mathrm{mmol})$ was gradually added under stirring at room temperature. After $1.5 \mathrm{~h}$, acetic anhydride $(918 \mathrm{mg}, 9 \mathrm{mmol})$ was dropwise added to the mixture at $0^{\circ} \mathrm{C}$. Then the mixture solution was stirred at room temperature for $6 \mathrm{~h}$ and then poured into $200 \mathrm{~mL}$ of ice water. After filtered, the solution was extracted with ethyl acetate, organic layer was separated and dried over anhydrous $\mathrm{Na}_{2} \mathrm{SO}_{4}$. The precipitate was purified by column chromatography to give light yellow powder of compound 4 (1.8g, 90\%). Melting points: $200{ }^{\circ} \mathrm{C}$. ${ }^{1} \mathrm{H}$ NMR $\left(400 \mathrm{MHz}, \mathrm{DMSO}-d_{6}\right), \delta=9.16(\mathrm{~d}, J=1.6 \mathrm{~Hz}, 1 \mathrm{H}), 9.12(\mathrm{~d}, J=1.6 \mathrm{~Hz}, 1 \mathrm{H}), 8.28\left(\mathrm{dd}, J_{l}=8.6\right.$ $\left.\mathrm{Hz}, J_{2}=1.8 \mathrm{~Hz}, 1 \mathrm{H}\right), 8.15(\mathrm{~m}, 2 \mathrm{H}), 8.06(\mathrm{~d}, J=8.0 \mathrm{~Hz}, 1 \mathrm{H}), 7.86(\mathrm{~d}, J=8.4 \mathrm{~Hz}, 1 \mathrm{H}), 7.78(\mathrm{~d}, J=8.8$ $\mathrm{Hz}, 1 \mathrm{H}), 7.55(\mathrm{~m}, 1 \mathrm{H}), 7.46(\mathrm{~m}, 1 \mathrm{H}), 4.56$ (q, $J=7.1 \mathrm{~Hz}, 2 \mathrm{H}), 2.74(\mathrm{~s}, 3 \mathrm{H}), 1.38$ (t, $J=7.0 \mathrm{~Hz}, 3 \mathrm{H})$.

\section{Synthesis of compound TCaP}

Compound 4 (500 mg, $1.35 \mathrm{mmol})$ and 4-diethylamino-salicylaldehyde (386 $\mathrm{mg}, 1 \mathrm{mmol})$ were dissolved in conc. $\mathrm{H}_{2} \mathrm{SO}_{4}(6 \mathrm{~mL})$ and stirred at $90{ }^{\circ} \mathrm{C}$ for $8 \mathrm{~h}$. After cooling to room temperature, the solution was added $70 \%$ perchloric acid $(6 \mathrm{~mL})$ then ice water $(200 \mathrm{~mL})$, filtered, and washed with water to afford crude product. The crude product was purified by column chromatography $\left(\mathrm{CH}_{2} \mathrm{Cl}_{2} / \mathrm{CH}_{3} \mathrm{OH}, 15: 1\right)$ to afford bluish violet solid (yield, $75 \%$ ). Melting points: $185{ }^{\circ} \mathrm{C}$. ${ }^{1} \mathrm{H}$ NMR $\left(400 \mathrm{MHz}, \mathrm{CDCl}_{3}\right) \delta=9.37(\mathrm{~s}, 2 \mathrm{H}), 8.40(\mathrm{~d}, J=7.6 \mathrm{~Hz}, 1 \mathrm{H}), 8.28(\mathrm{t}, J=7.4 \mathrm{~Hz}, 2 \mathrm{H}), 8.15(\mathrm{~d}, J=8.4$ $\mathrm{Hz}, 1 \mathrm{H}), 8.06(\mathrm{~d}, J=8.0 \mathrm{~Hz}, 1 \mathrm{H}), 7.76(\mathrm{~m}, 6 \mathrm{H}), 7.42(\mathrm{~s}, 1 \mathrm{H}), 7.25$ (d, $J=9.6 \mathrm{~Hz}, 1 \mathrm{H}), 4.49$ (q, $J=7.1$ $\mathrm{Hz}, 2 \mathrm{H}), 3.79\left(\mathrm{dd}, J_{1}=13.7 \mathrm{~Hz}, J_{2}=6.8 \mathrm{~Hz}, 4 \mathrm{H}\right), 1.55(\mathrm{t}, J=7.0 \mathrm{~Hz}, 3 \mathrm{H}), 1.45(\mathrm{t}, J=7.0 \mathrm{~Hz}, 6 \mathrm{H}) .{ }^{13} \mathrm{C}$ (101 MHz, $\left.\mathrm{CDCl}_{3}\right)$ 173.52, 167.57, 156.55, 147.62, 145.14, 144.71, 140.37, 132.16, 130.43, 128.64, $128.31,128.16,127.34,124.39,123.93,122.92$, 122.78, 122.03, 121.66, 118.67, 118.03, 117.80, 116.84, 111.52, 111.13, 110.16, 108.23, 96.95, 46.59, 38.88, 13.64, 12.28. HRMS (ESI): calcd. for $\mathrm{C}_{34} \mathrm{H}_{30} \mathrm{~N}_{3} \mathrm{OS}^{+},[\mathrm{M}+\mathrm{H}]^{+}, \mathrm{m} / \mathrm{z}, 528.2110$, found: 528.2115 . 


\section{Synthesis route of the fluorescent probe $\mathrm{CaP}$.}

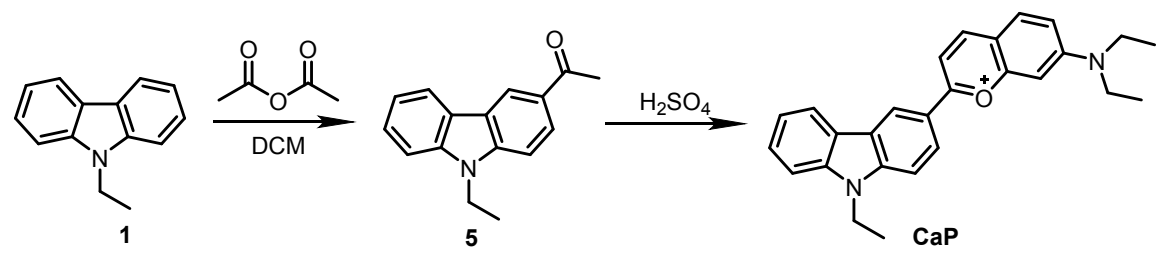

Scheme S3. Synthesis route of CaP.

\section{Synthesis of compound 5}

Compound 1 (975 mg, $5 \mathrm{mmol}$ ) was added to $4 \mathrm{~mL} \mathrm{DCM}, \mathrm{AlCl}_{3}(1.33 \mathrm{~g}, 10 \mathrm{mmol})$ was gradually added under stirring at room temperature. After $1.5 \mathrm{~h}$, acetic anhydride $(510 \mathrm{mg}, 5 \mathrm{mmol})$ was dropwise added to the mixture at $0{ }^{\circ} \mathrm{C}$. Then the mixture solution was stirred at room temperature for $6 \mathrm{~h}$ and then poured into $200 \mathrm{~mL}$ of ice water. After filtered, the solution was extracted with ethyl acetate, organic layer was separated and dried over anhydrous $\mathrm{Na}_{2} \mathrm{SO}_{4}$. The precipitate was purified by column chromatography to give white powder of compound 5 (1.1g, 94\%). Melting points: $95{ }^{\circ} \mathrm{C} .{ }^{1} \mathrm{H}$ NMR $\left(400 \mathrm{MHz}, \mathrm{DMSO}-d_{6}\right) \delta 8.88(\mathrm{~d}, J=1.2 \mathrm{~Hz}, 1 \mathrm{H}), 8.31(\mathrm{~d}, J=8.0 \mathrm{~Hz}, 1 \mathrm{H}), 8.09\left(\mathrm{dd}, J_{1}=8.6 \mathrm{~Hz}, J_{2}=\right.$ $1.8 \mathrm{~Hz}, 1 \mathrm{H}), 7.72(\mathrm{~m}, 2 \mathrm{H}), 7.64(\mathrm{~m}, 1 \mathrm{H}), 7.27(\mathrm{~m}, 1 \mathrm{H}), 4.49(\mathrm{q}, J=7.1 \mathrm{~Hz}, 2 \mathrm{H}), 2.69(\mathrm{~s}, 3 \mathrm{H}), 1.32(\mathrm{t}, J$ $=7.2 \mathrm{~Hz}, 3 \mathrm{H})$.

\section{Synthesis of compound CaP}

Compound 2 (474 mg, $2 \mathrm{mmol}$ ) and 4-diethylamino-salicylaldehyde (386 mg, $1 \mathrm{mmol}$ ) were dissolved in conc. $\mathrm{H}_{2} \mathrm{SO}_{4}(3 \mathrm{~mL})$ and stirred at $90{ }^{\circ} \mathrm{C}$ for $5 \mathrm{~h}$. After cooling to room temperature, the solution was added $70 \%$ perchloric acid $(0.5 \mathrm{~mL})$ then ice water $(100 \mathrm{~mL})$, filtered, and washed with water to afford crude product. The crude product was purified by silica gel flash chromatography $\left(\mathrm{CH}_{2} \mathrm{Cl}_{2} / \mathrm{CH}_{3} \mathrm{OH}\right.$, $20: 1)$ to afford bluish violet solid (yield, $88 \%$ ). Melting points: $210{ }^{\circ} \mathrm{C}{ }^{1} \mathrm{H}$ NMR (400 MHz, DMSO- $d_{6}$ ) $\delta 9.31(\mathrm{~s}, 1 \mathrm{H}), 8.80(\mathrm{~d}, J=8.4 \mathrm{~Hz}, 1 \mathrm{H}), 8.49(\mathrm{~d}, J=8.0 \mathrm{~Hz}, 1 \mathrm{H}), 8.36(\mathrm{~d}, J=8.0 \mathrm{~Hz}, 1 \mathrm{H}), 8.24(\mathrm{~d}, J=$ $8.4 \mathrm{~Hz}, 1 \mathrm{H}), 7.98$ (d, $J=9.2 \mathrm{~Hz}, 1 \mathrm{H}), 7.92$ (d, $J=9.2 \mathrm{~Hz}, 1 \mathrm{H}), 7.77$ (d, $J=8.0 \mathrm{~Hz}, 1 \mathrm{H}), 7.60$ (t, $J=7.6$ $\mathrm{Hz}, 1 \mathrm{H}), 7.42(\mathrm{~m}, 3 \mathrm{H}), 4.57$ (q, $J=6.9 \mathrm{~Hz}, 2 \mathrm{H}), 3.73$ (q, $J=6.8 \mathrm{~Hz}, 4 \mathrm{H}), 1.39$ (t, $J=7.0 \mathrm{~Hz}, 3 \mathrm{H}), 1.28$ $(\mathrm{t}, J=6.8 \mathrm{~Hz}, 6 \mathrm{H}) .{ }^{13} \mathrm{C} \mathrm{NMR}\left(100 \mathrm{MHz}, \mathrm{DMSO}-d_{6}\right) \delta 168.41,159.30,156.08,149.13,143.70,141.01$, $132.57,127.79,126.44,123.81,122.76,122.55,121.53,121.21,120.27,118.04,117.96,111.02,110.84$, 109.23, 96.42, 45.88, 38.07, 14.31, 12.98. HRMS (ESI): calcd. for $\mathrm{C}_{27} \mathrm{H}_{27} \mathrm{~N}_{2} \mathrm{O}^{+},[\mathrm{M}]^{+}, \mathrm{m} / \mathrm{z}, 395.2123$, found: 395.2126 .

\section{Measurements of optical spectroscopy properties.}


Unless otherwise noted, all the measurements were made according to the following procedure. The concentration of the probes stock solution was $1.0 \mathrm{mM}$ in $\mathrm{CH}_{3} \mathrm{CN}$, and the analyte stock solutions were prepared in the deionized water at the appropriate concentration. The probe was added to a $10 \mathrm{~mL}$ color comparison tube. CaP was diluted to $10 \mu \mathrm{M}$ in $10 \mathrm{mM}$ HEPES buffer $\left(20 \% \mathrm{CH}_{3} \mathrm{CN}\right)$. The spectrum experiments were conducted with a $1 \mathrm{~cm}$ standard quartz cell at room temperature. The fluorescence intensity of CaP was measured at $\lambda_{\mathrm{ex}}=270 \mathrm{~nm}$ and TCaP was measured at $\lambda_{\mathrm{ex}}=370 \mathrm{~nm}$. The excitation slit widths were $5 \mathrm{~nm}$, and the emission slit widths were $5 \mathrm{~nm}$.

\section{Spectral measurements of selectivity}

The stock solution of $\mathbf{C a P}(1 \mathrm{mM})$ was prepared in $\mathrm{CH}_{3} \mathrm{CN}$. The various testing analytes stock solutions ( $\mathrm{FeSO}_{4}, \mathrm{Hcy}, \mathrm{NaHS}, \mathrm{NaClO}, \mathrm{Cys}, \mathrm{GSH}, \mathrm{H}_{2} \mathrm{O}_{2}$, tert-butyl peroxide (TBHP), KF, NaF, KI, $\mathrm{CuCl}_{2}, \mathrm{KSCN}$, $\mathrm{MgCl}_{2}, \mathrm{NaBr}, \mathrm{NaHCO}_{3}, \mathrm{NaNO}_{2}, \mathrm{NaNO}_{3}, \mathrm{Na}_{2} \mathrm{~S}_{2} \mathrm{O}_{3}, \mathrm{Na}_{2} \mathrm{SO}_{4}, \mathrm{BaCl}_{2}, \mathrm{Na}_{2} \mathrm{HPO}_{4}, \mathrm{CHCP}$, Citrate, $\mathrm{AgNO}_{3}$, $\mathrm{NH}_{2} \mathrm{NH}_{2}$, sodium pyruvate, $\mathrm{ZnCl}_{2}, \mathrm{NaOAc}, \mathrm{CH}_{3} \mathrm{CHO}, \mathrm{CHOCHO}, \mathrm{HCHO}, \mathrm{CaCl}_{2}, \mathrm{NaN}_{3}$, only the probe CaP and $\mathrm{NaHSO}_{3}$ ) were prepared at $100 \mathrm{mM}$ in twice distilled water, and the di-t-butyl peroxide (DTBP) stock solution (100 mM) was prepared in the DMSO. The test solution contained CaP $(10 \mu \mathrm{M})$, HEPES buffer ( $\left.\mathrm{pH} 7.0,10 \mathrm{mM}, 20 \% \mathrm{CH}_{3} \mathrm{CN}\right)$ and the anions and cations at $2.5 \mathrm{mM}$, ROS at $100 \mu \mathrm{M}$, representative amino acid at $200 \mu \mathrm{M}, \mathrm{GSH}$ at $1 \mathrm{mM}, \mathrm{Na}_{2} \mathrm{~S}$ at $50 \mu \mathrm{M}$ and other analytes at $500 \mu \mathrm{M}$. For the selectivity of FA, the probe were pre-treated with $50 \mu \mathrm{M} \mathrm{NaHSO}$, then the appropriate concentration of each analytes were added. After that, the fluorescence spectra were measured.

\section{Detection limit of CaP for $\mathrm{SO}_{2}$}

The detection limit was based on a reported method ${ }^{1}$. According to the result of titrating experiment, the fluorescence ratio intensities $\left(\mathrm{I}_{370} / \mathrm{I}_{630}\right)$ of CaP treated with different $\mathrm{NaHSO}_{3}$ were normalized between the minimum intensity and the maximum intensity. A linear regression curve was then fitted to the normalized fluorescent intensity data and the point at which this line crossed the axis was considered as the detection limit $\left(7.3 \times 10^{-7} \mathrm{M}\right)$.

\section{Kinetic analysis of the reaction of probe against $\mathrm{SO}_{2}$ and $\mathrm{FA}$}

Kinetic parameters of the probe $(10 \mu \mathrm{M})$ were determined by fluorescence spectroscopy with a F4600 fluorescence spectrophotometer (Hitachi). The changes of fluorescence intensity upon addition of 50 $\mu \mathrm{M} \mathrm{NaHSO}{ }_{3}$ was recorded at a scan rate of $3 \mathrm{~s}$ and upon addition of $200 \mu \mathrm{M}$ FA was recorded at a scan rate of 3 s. The time-dependent fluorescence change of CaP are shown in Figure S4c.

\section{Naked-eye detection of the reversibility of CaP}


CaP $(10 \mu \mathrm{M})$ was dissolved in $10 \mathrm{mM}$ HEPES buffer containing $20 \% \mathrm{CH}_{3} \mathrm{CN}$ as a cosolvent. $\mathrm{NaHSO}_{3}$ and FA with mole ratio of 1:4 were added alternately for reversibility. The results of the experiment are shown in Supplementary Video S1 and Figure 2c.

\section{Cell culture and cell cytotoxicity assays}

\section{Cell culture}

HeLa cells were cultured in Dulbecco's Modified Eagle Medium media (DMEM, Hyclone) supplemented with $10 \%$ fetal bovine serum (FBS, Sijiqing), penicillin (100 U/ml, Hyclone) and streptomycin sulfate $\left(100 \mathrm{U} / \mathrm{ml}\right.$, Hyclone) under an atmosphere of $5 \% \mathrm{CO}_{2}$ and $95 \%$ air at $37{ }^{\circ} \mathrm{C}$.

\section{Cytotoxicity assays}

The cytotoxicity of CaP to HeLa and U251 cells were studied by standard MTT assays. $2 \times 10^{4}$ cells/mL HeLa and U251 cells were seeded in 96-well plates respectively and then incubated with various concentrations of $\mathbf{C a P}(0-50 \mu \mathrm{M})$ for $24 \mathrm{~h}$. After that $10 \mu \mathrm{L}$ MTT $(5 \mathrm{mg} / \mathrm{mL})$ was added to each well. After incubated for $4 \mathrm{~h}$, the supernatants were aspirated and $100 \mu \mathrm{L}$ DMSO was added. The absorbance of the solution at $570 \mathrm{~nm}$ was recorded using microplate reader. The cell viability $(\%)=$ $\left(\mathrm{OD}_{\text {sample }}-\mathrm{OD}_{\text {blank }}\right) /\left(\mathrm{OD}_{\text {control }}-\mathrm{OD}_{\text {blank }}\right) \times 100 \%$. OD sample denotes the cells cultured with different concentrations of $\mathbf{C a P}, \mathrm{OD}_{\text {control }}$ denotes the cells incubated with culture medium, $\mathrm{OD}_{\text {blank }}$ denotes only the culture medium.

\section{Cell imaging experiments}

\section{Photophysical properties of the probe}
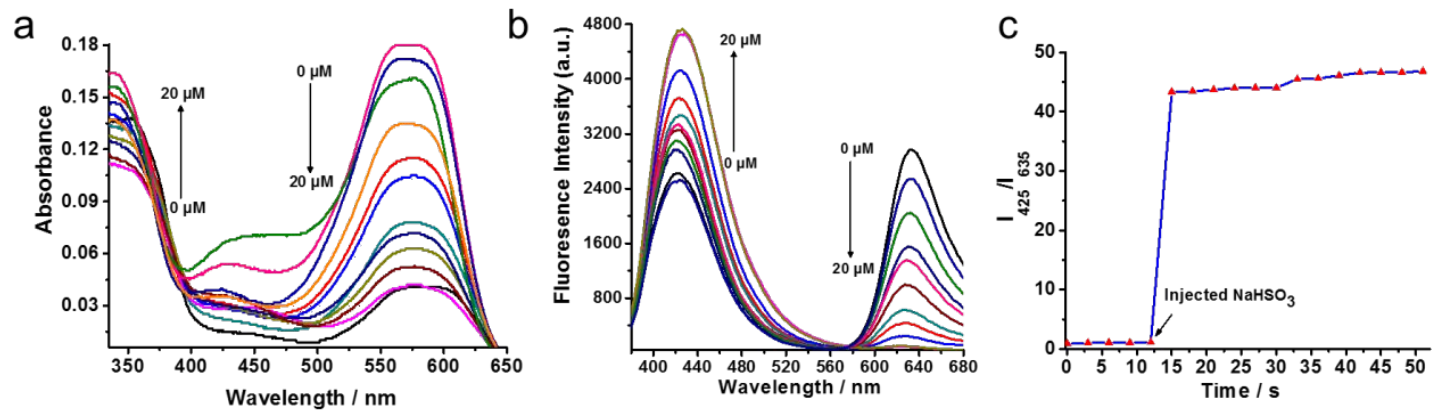

Figure S1. Optical properties of the probe TCaP (buffer: $10 \mathrm{mM}$ HEPES buffer, $\mathrm{pH} 7.0,20 \% \mathrm{CH}_{3} \mathrm{CN}$ ). a. Absorption spectra of TCaP $(10 \mu \mathrm{M})$ upon addition of $\mathrm{NaHSO}_{3}(0-20 \mu \mathrm{M})$. $\mathbf{b}$, Fluorescence spectra of TCaP $(10 \mu \mathrm{M})$ upon addition of $\mathrm{NaHSO}_{3}(0-20 \mu \mathrm{M})$. c, The relationship between the fluorescence intensity ratios $\left(\mathrm{I}_{425} / \mathrm{I}_{635}\right)$ and $\left[\mathrm{HSO}^{-}\right]$d, Time-dependent fluorescence intensity ratios $\left(\mathrm{I}_{425} / \mathrm{I}_{635}\right)$ of TCaP upon addition of $\mathrm{NaHSO}_{3}(20 \mu \mathrm{M})$. 

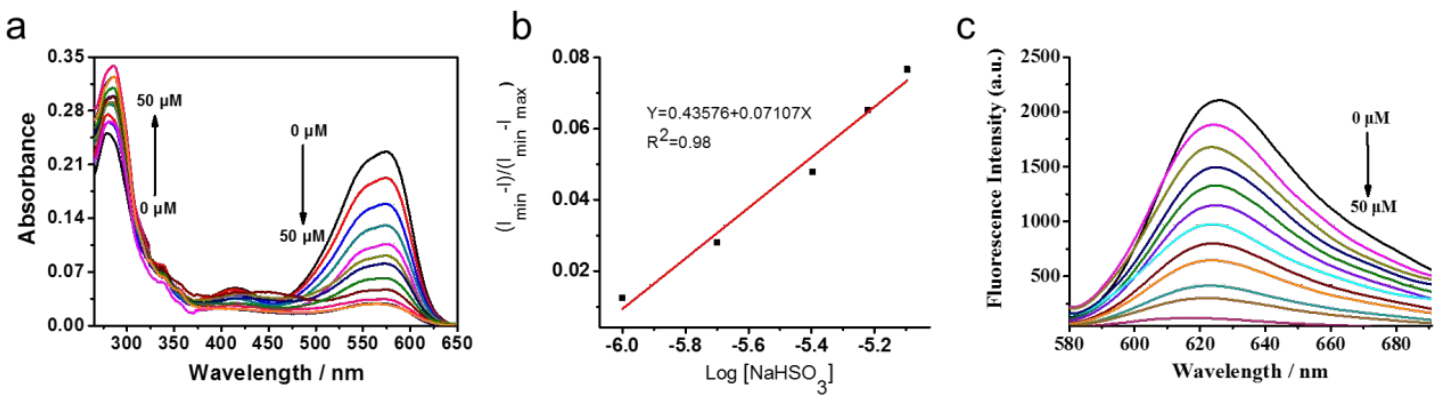

Figure S2. a. Absorption spectra of $\mathbf{C a P}(10 \mu \mathrm{M})$ upon addition of $\mathrm{NaHSO}_{3}(0,2,5,8,10,12,15,20,25,30,40$ and $50 \mu \mathrm{M})$. b. Normalized response of the fluorescence signal $(\mathbf{C a P})$ by changing the concentration of $\mathrm{NaHSO}_{3}$. c. Fluorescence spectral changes of the probe $\mathbf{C a P}(10 \mu \mathrm{M})$ upon addition of increasing concentrations $(0,2,5,8,10,12,15,20,25,30,40$ and 50 $\mu \mathrm{M})$ of $\mathrm{NaHSO}_{3} \cdot \lambda_{\mathrm{ex}}=570 \mathrm{~nm}$

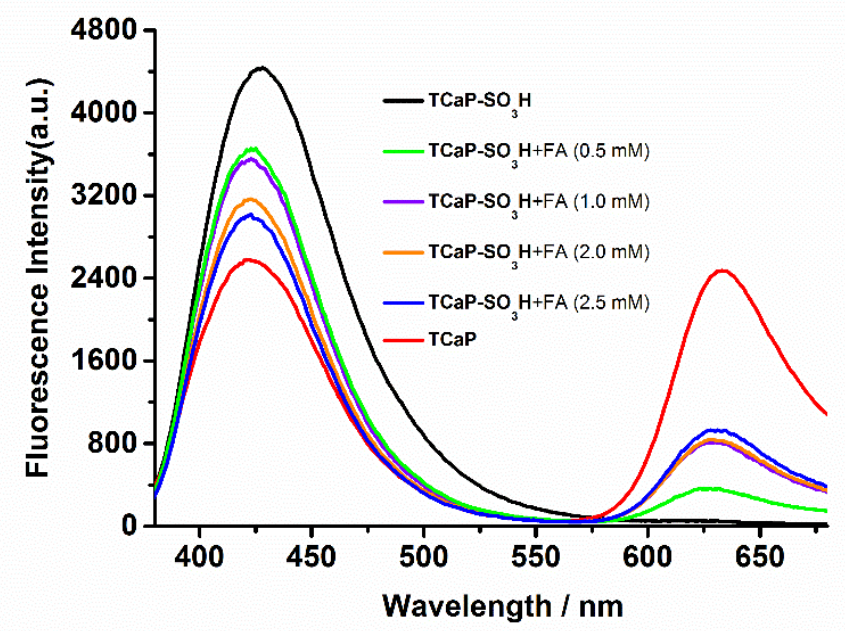

Figure S3. Fluorescence spectral changes of the $\mathbf{T C a P - S O} \mathbf{S}_{3} \mathbf{H}(10 \mu \mathrm{M}$ TCaP with $20 \mu \mathrm{M} \mathrm{NaHSO})$ upon addition of increasing concentrations of FA for $30 \mathrm{~min}$. $\lambda_{\mathrm{ex}}=370 \mathrm{~nm}$
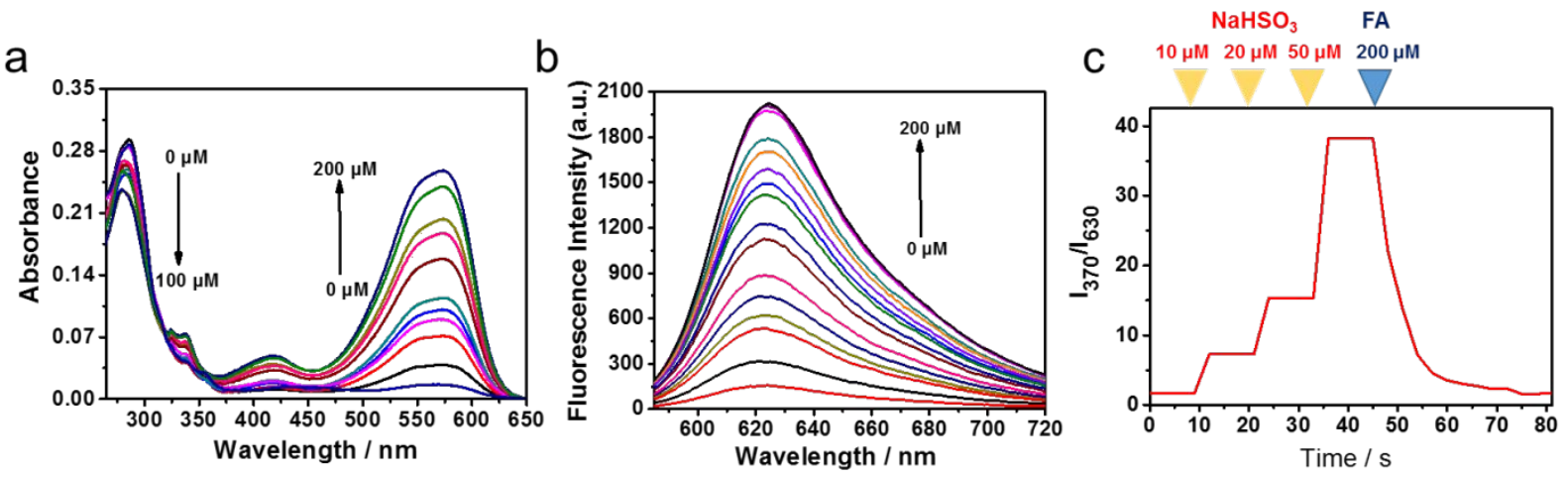

Figure S4. a. Absorption spectra of $\mathbf{C a P}(10 \mu \mathrm{M})$ with $\mathrm{NaHSO}_{3}(50 \mu \mathrm{M})$ upon addition various concentrations of FA $(0$, 10 , 20, 30, 40, 50, 60, 80, 100, 150 and $200 \mu \mathrm{M})$. b. Fluorescence spectral changes of CaP-SO $\mathbf{H}(10 \mu \mathrm{M} \mathbf{C a P}$ with $50 \mu \mathrm{M}$ $\mathrm{NaHSO}_{3}$ ) upon addition of increasing concentrations $(0,10,20,30,40,50,60,70,80,90,100,120,150,180$ and $200 \mu \mathrm{M})$ 
of FA. $\lambda_{\text {ex }}=570 \mathrm{~nm}$. c. Fluorescence intensity ratio $\left(\mathrm{I}_{370} / \mathrm{I}_{630}\right)$ of $\mathrm{CaP}$ upon addition of $\mathrm{NaHSO}_{3}$ and $\mathrm{FA}$. The concentrations of $\mathrm{NaHSO}_{3}$ and FA are shown in the figures. Excitation: $270 \mathrm{~nm}$.

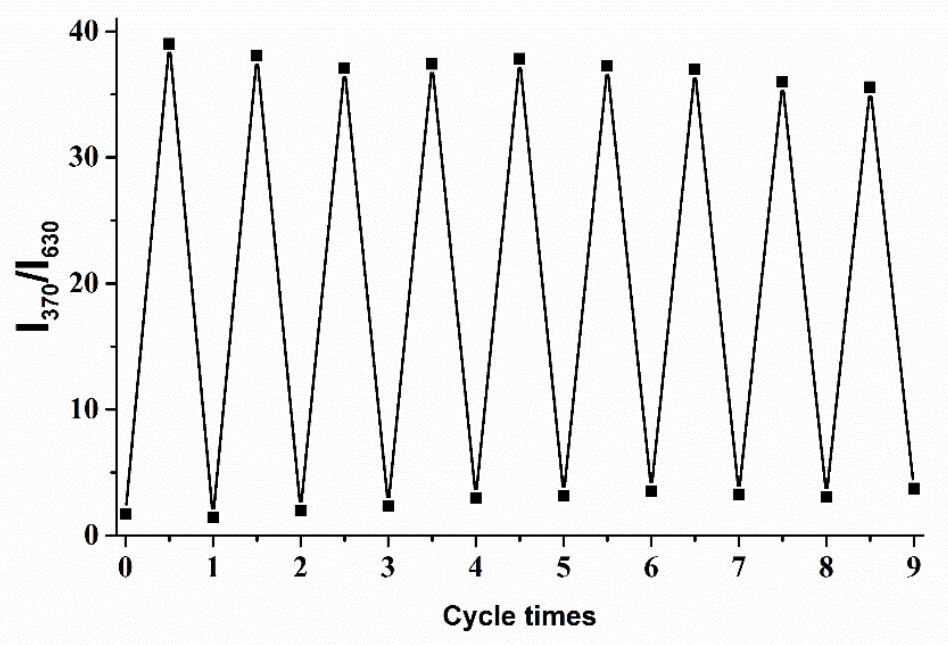

Figure S5. Fluorescence intensity ratio $\left(\mathrm{I}_{370} / \mathrm{I}_{630}\right)$ of $\mathbf{C a P}(10 \mathrm{mM})$ upon the alternate addition of $\mathrm{NaHSO}_{3}-\mathrm{FA}$ with mole ratio of 1:4 in HEPES buffer ( $\left.\mathrm{pH} 7.0,20 \% \mathrm{CH}_{3} \mathrm{CN}\right)$. Excitation: $270 \mathrm{~nm}$. 
a

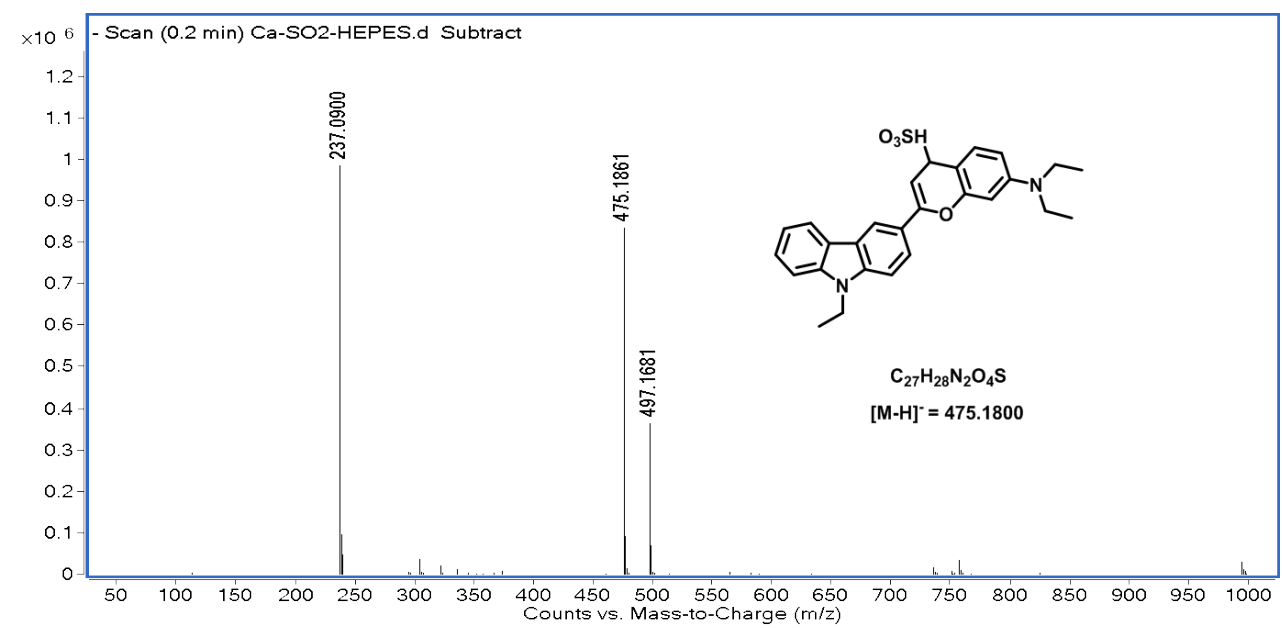

b

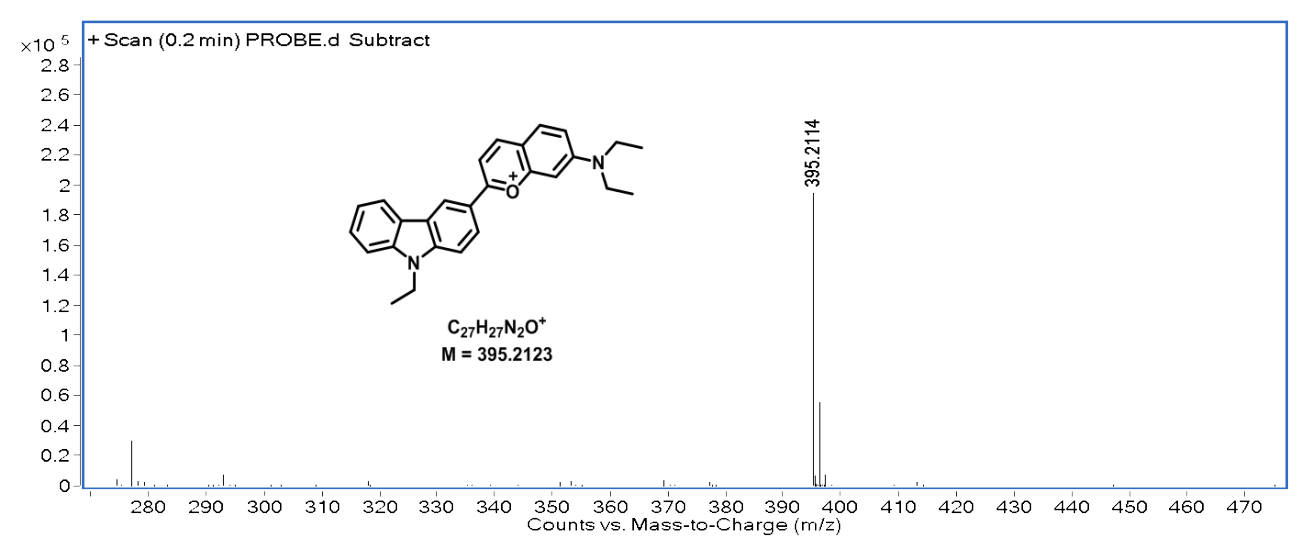

Figure S6. a. HR-MS spectrum of the reaction of $20 \mu \mathrm{M} \mathrm{CaP}$ with $100 \mu \mathrm{M} \mathrm{NaHSO}_{3}$ in $\mathrm{HEPES}\left(20 \% \mathrm{CH}_{3} \mathrm{CN}\right)$. b. HR-MS spectrum of the mixture of $20 \mu \mathrm{M} \mathrm{CaP}$ with $100 \mu \mathrm{M} \mathrm{NaHSO}_{3}$ upon addition of $400 \mu \mathrm{M}$ FA in HEPES $\left(20 \% \mathrm{CH}_{3} \mathrm{CN}\right)$.

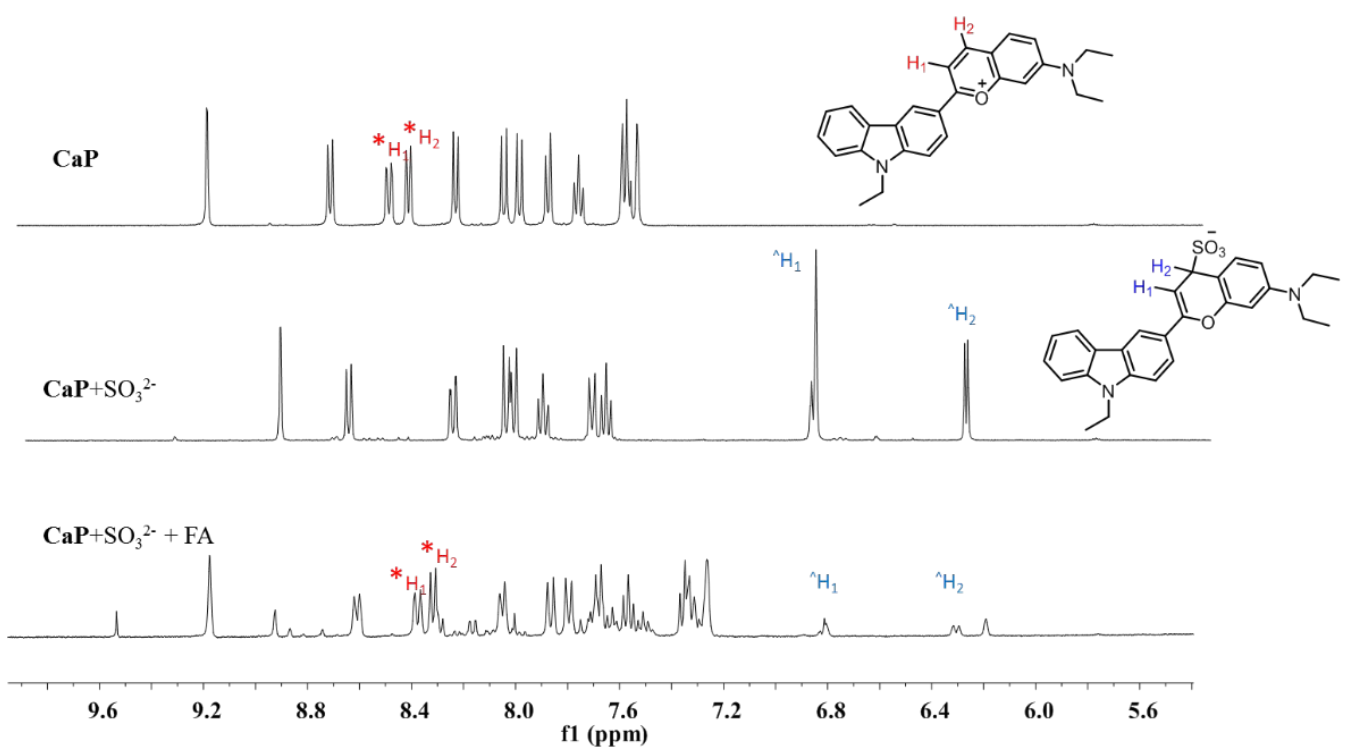

Figure S7. ${ }^{1} \mathrm{H}$ NMR spectral changes of Probe $\mathbf{C a P}(20.0 \mathrm{mM})$ in the presence of $\mathrm{Na}_{2} \mathrm{SO}_{3}(100 \mathrm{mM})$ and the mixture of 20.0 $\mathrm{mM} \mathrm{CaP}$ with $100 \mathrm{mM} \mathrm{Na}_{2} \mathrm{SO}_{3}$ upon addition of $400 \mathrm{mM} \mathrm{FA}$ in DMSO- $\mathrm{d}_{6} / \mathrm{D}_{2} \mathrm{O}(\mathrm{v} / \mathrm{v}=4: 1)$ solution. 


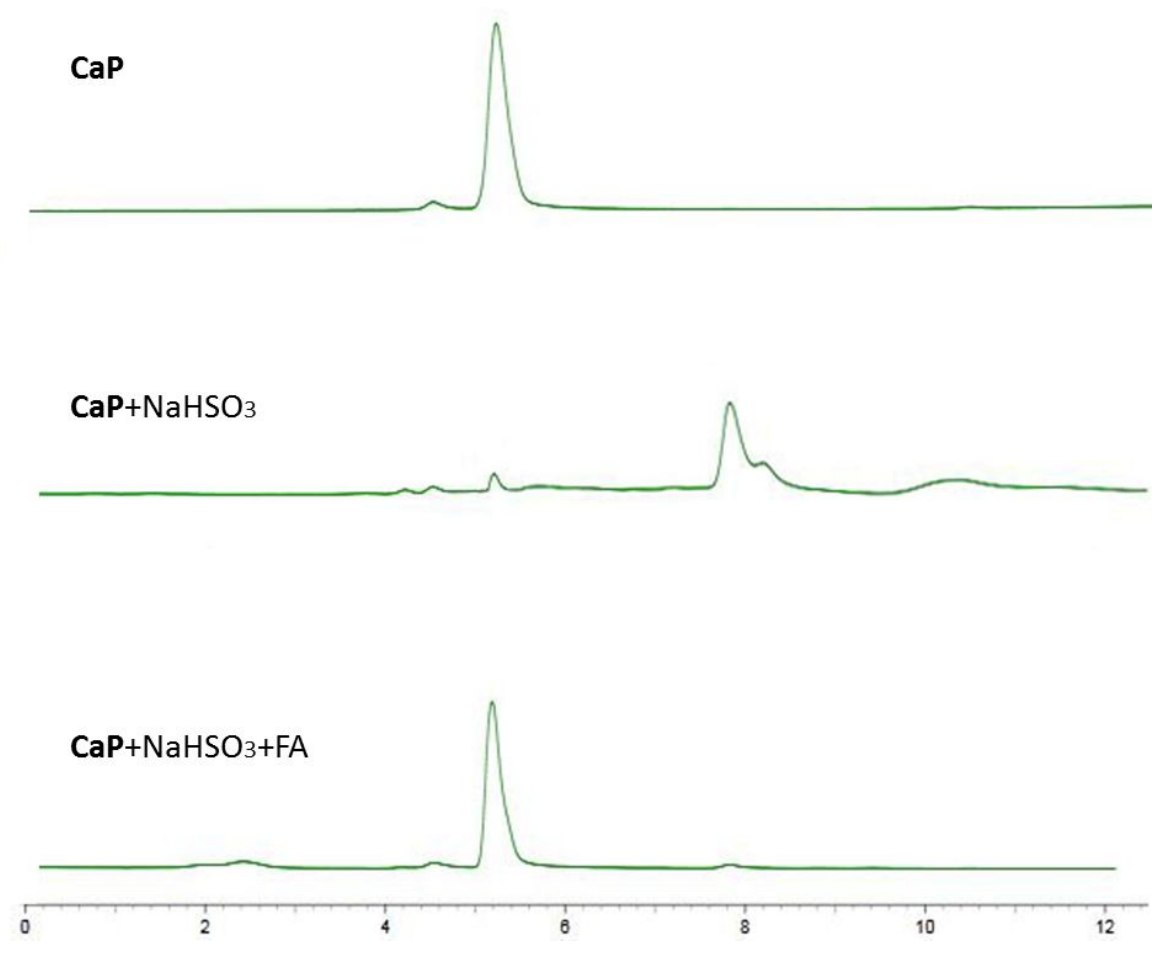

Figure S8. The HPLC chromatograms for the mixture of CaP, $\mathrm{NaHSO}_{3}$ and FA in HEPES buffer $(10 \mathrm{mM}$, pH 7.0, containing $\left.20 \% \mathrm{CH}_{3} \mathrm{CN}\right)$.

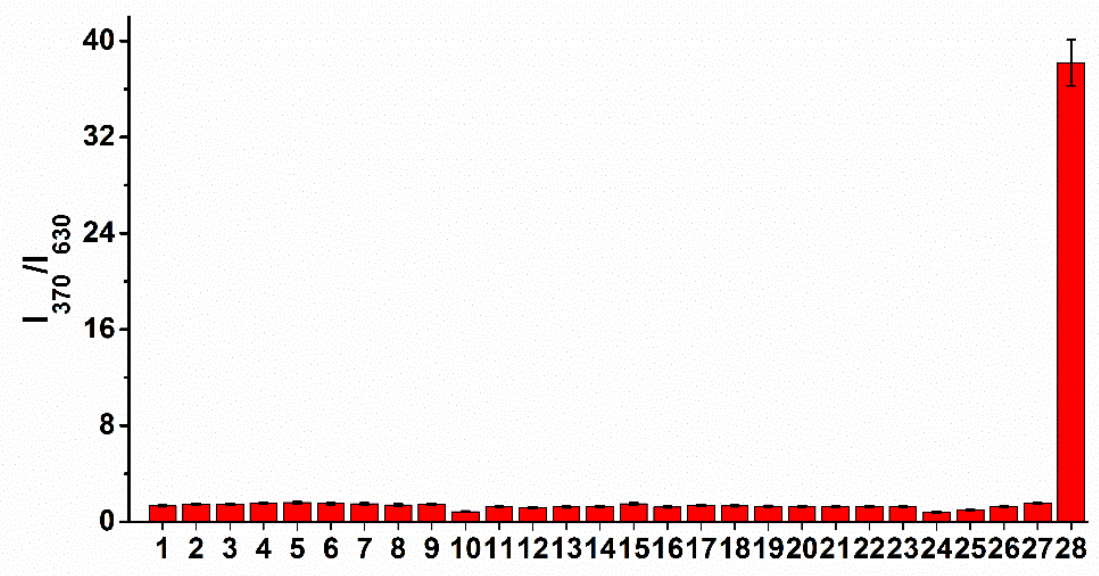

Figure S9. Fluorescent ratio $\left(\mathrm{I}_{370} / \mathrm{I}_{630}\right)$ of the probe CaP $(10 \mu \mathrm{M})$ to various relevant analytes in HEPES buffer $(20 \%$ $\left.\mathrm{CH}_{3} \mathrm{CN}\right) .1, \mathrm{FeSO}_{4}(2.5 \mathrm{mM}) ; 2$, Hcy $(200 \mu \mathrm{M}) ; 3$, NaHS $(50 \mu \mathrm{M}) ; 4, \mathrm{NaClO}(100 \mu \mathrm{M}) ; 5$, Cys $(200 \mu \mathrm{M}) ; 6, \mathrm{GSH}(1 \mathrm{mM}) ; 7$, $\mathrm{H}_{2} \mathrm{O}_{2}(100 \mu \mathrm{M}) ; 8$, tert-butyl hydroperoxide (TBHP) $(100 \mu \mathrm{M}) ; 9$, di-t-butyl peroxide (DTBP) $(100 \mu \mathrm{M}) ; 10, \mathrm{NaF}(2.5 \mathrm{mM})$; 11, KI (2.5 mM); 12, $\mathrm{CuCl}_{2}(2.5 \mathrm{mM}) ; 13, \mathrm{KSCN}(2.5 \mathrm{mM}) ; 14, \mathrm{MgCl}_{2}(2.5 \mathrm{mM}) ; 15, \mathrm{NaBr}(2.5 \mathrm{mM}) ; 16, \mathrm{NaHCO}_{3}(2.5$ $\mathrm{mM}) ; 17, \mathrm{NaNO}_{2}(2.5 \mathrm{mM}) ; 18, \mathrm{NaNO}_{3}(2.5 \mathrm{mM}) ; 19, \mathrm{Na}_{2} \mathrm{~S}_{2} \mathrm{O}_{3}(2.5 \mathrm{mM}) ; 20, \mathrm{Na}_{2} \mathrm{SO}_{4}(2.5 \mathrm{mM}) ; 21, \mathrm{ZnCl}_{2}(2.5 \mathrm{mM}) ; 22$, $\mathrm{NaOAc}(2.5 \mathrm{mM}) ; 23, \mathrm{CaCl}_{2}(2.5 \mathrm{mM}) ; 24, \mathrm{NaN}_{3}(2.5 \mathrm{mM}) ; 25$, only the probe CaP $(10 \mu \mathrm{M}) ; 26 . \mathrm{ONOO}^{-}(10 \mu \mathrm{M}) ; 27 . \mathrm{H}_{2} \mathrm{~S}_{2}$ $(10 \mu \mathrm{M}) ; 28 . \mathrm{NaHSO}_{3}(50 \mu \mathrm{M})$. Error bars represent mean values $\pm \mathrm{SD} .(\mathrm{n}=3)$ 
(a) Cysteine

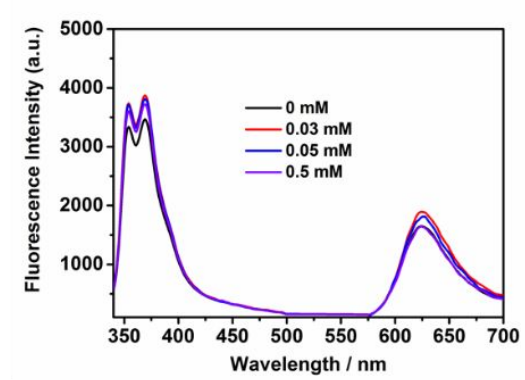

(c) Homocysteine

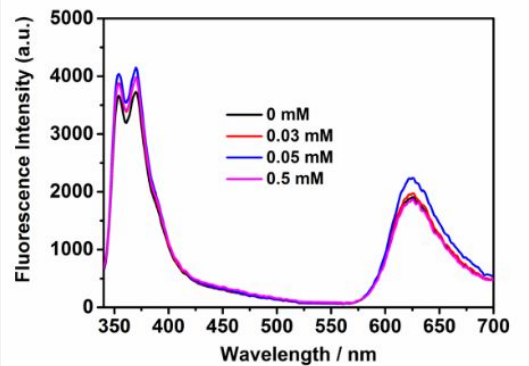

(b) Glutathione

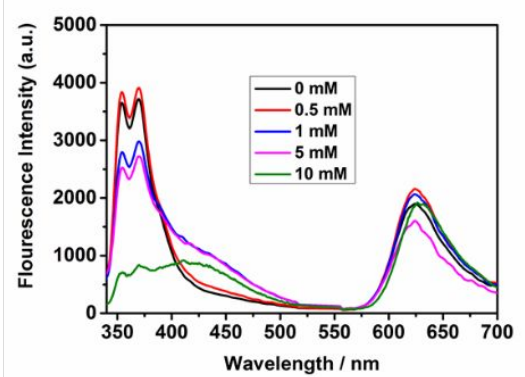

(d) Hydrogen sulfide $\left(\mathrm{H}_{2} \mathrm{~S}\right)$

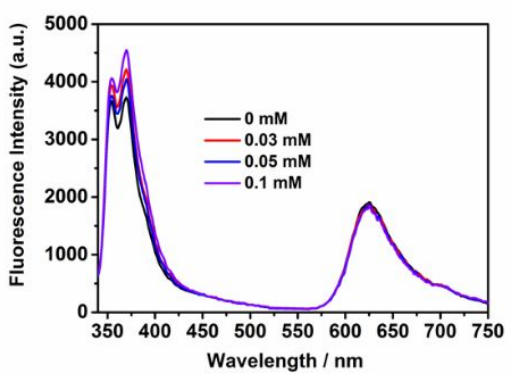

Figure S10. Spectral changes of $\mathrm{CaP}$ in the presence of some small-molecule biological thiols.

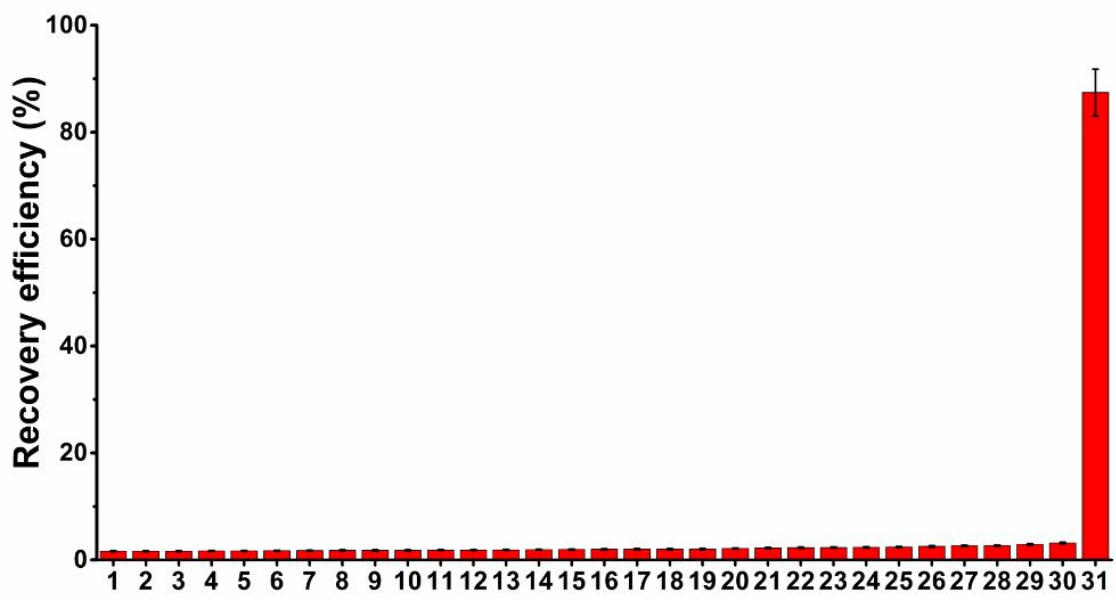

Figure S11. Fluorescent recovery efficiency of the mixture of $\mathbf{C a P}(10 \mu \mathrm{M})$ in the presence of $50 \mu \mathrm{M} \mathrm{NaHSO} \mathrm{O}_{3}$ upon addition of various relevant analytes in HEPES buffer $\left(20 \% \mathrm{CH}_{3} \mathrm{CN}\right) .1, \mathrm{NaHSO}_{3}(50 \mu \mathrm{M}) ; 2, \mathrm{Na}_{2} \mathrm{~S}_{2} \mathrm{O}_{3}(2.5 \mathrm{mM}) ; 3, \mathrm{NaClO}$ $(100 \mu \mathrm{M}) ; 4, \mathrm{BaCl}_{2}(2.5 \mathrm{mM}) ; 5, \mathrm{NaHCO}_{3}(2.5 \mathrm{mM}) ; 6, \mathrm{Na}_{2} \mathrm{~S}(50 \mu \mathrm{M}) ; 7$, KF (2.5 mM); 8, $\mathrm{Na}_{2} \mathrm{HPO}_{4}(2.5 \mathrm{mM}) ; 9$, 4nitrobenzaldehyde $(500 \mu \mathrm{M}) ; 10$, DTBP $(100 \mu \mathrm{M}) ; 11, \mathrm{NaNO}_{2}(2.5 \mathrm{mM}) ; 12, \mathrm{CH}_{3} \mathrm{CHO}(500 \mu \mathrm{M}) ; 13$, Sodium pyruvate $(500$ $\mu \mathrm{M}) ; 14, \mathrm{KSCN}(2.5 \mathrm{mM}) ; 15, \mathrm{NH}_{2} \mathrm{NH}_{2}(500 \mu \mathrm{M}) ; 16, \mathrm{NaOAc}(2.5 \mathrm{mM}) ; 17$, GSH (1 mM); 18, $\mathrm{Na}_{2} \mathrm{SO}_{4}(2.5 \mathrm{mM}) ; 19, \mathrm{CaCl}_{2}$ (2.5 mM); 20, Citrate (2.5 mM); 21, TBHP (100 $\mu \mathrm{M}) ; 22$, KI (2.5 mM); 23, $\mathrm{ZnCl}_{2}(2.5 \mathrm{mM}) ; 24, \mathrm{NaBr}(2.5 \mathrm{mM}) ; 25$, Cys $(200 \mu \mathrm{M}) ; 26, \mathrm{AgNO}_{3}(2.5 \mathrm{mM}) ; 27, \mathrm{H}_{2} \mathrm{O}_{2}(100 \mu \mathrm{M}) ; 28, \mathrm{MgCl}_{2}(2.5 \mathrm{mM}) ; 29, \mathrm{NaNO}_{3}(2.5 \mathrm{mM}) ; 30, \mathrm{CHOCHO}(500 \mu \mathrm{M})$; 31 , FA $(400 \mu \mathrm{M})$ Recovery efficiency $(\%)=\mathrm{R}_{\text {probe }} / \mathrm{R}_{\text {sample }} * 100 ; \mathrm{R}=$ Ratio $\left(\mathrm{I}_{370} / \mathrm{I}_{630}\right)$. Error bars represent mean values $\pm \mathrm{SD}$. $(\mathrm{n}=3)$. 


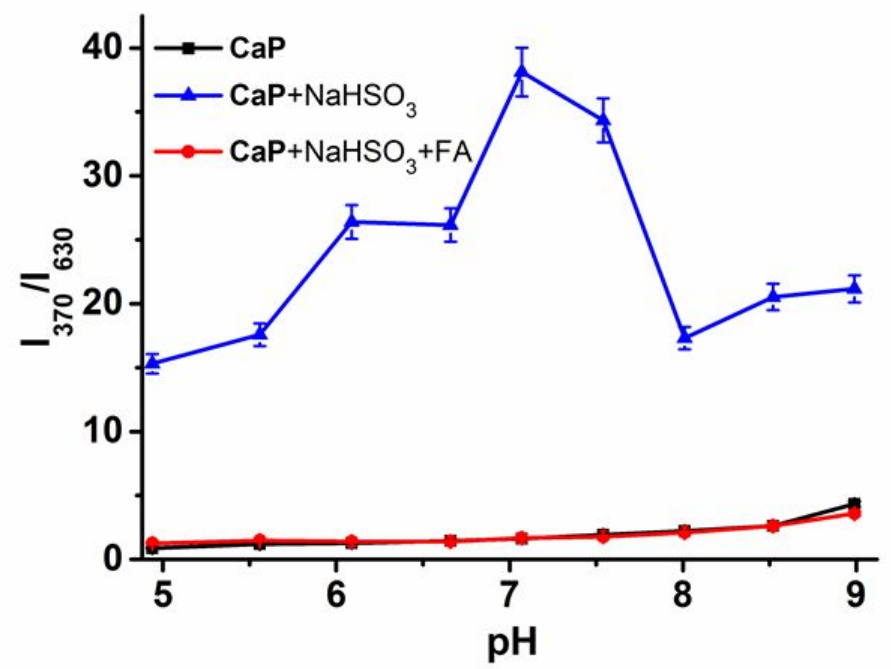

Figure S12. Fluorescent ratios $\left(\mathrm{I}_{370} / \mathrm{I}_{630}\right)$ of $\mathbf{C a P}(10 \mu \mathrm{M})$ toward $\mathrm{SO}_{2}(50 \mu \mathrm{M})$ and $\mathrm{FA}(200 \mu \mathrm{M})$ in $\mathrm{HEPES}\left(20 \% \mathrm{CH}{ }_{3} \mathrm{CN}\right)$ at various $\mathrm{pH}$ values.

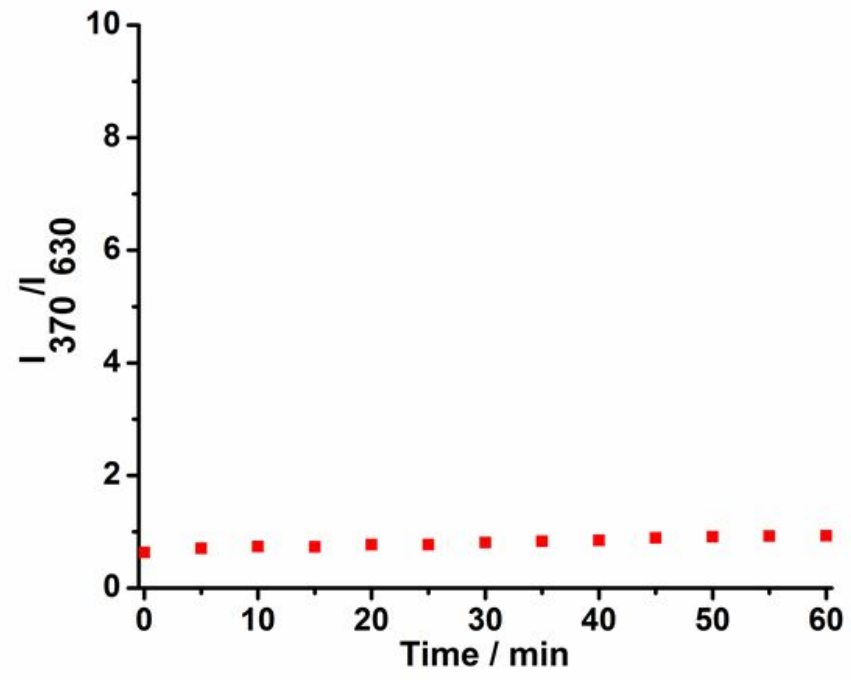

Figure S13. Photostability profiles of the CaP under UV-irradiated $(365 \mathrm{~nm})$. The fluorescent ratios $\left(\mathrm{I}_{370} / \mathrm{I}_{630}\right)$ were continuously monitored.

\section{Bioimaging application of $\mathrm{CaP}$}




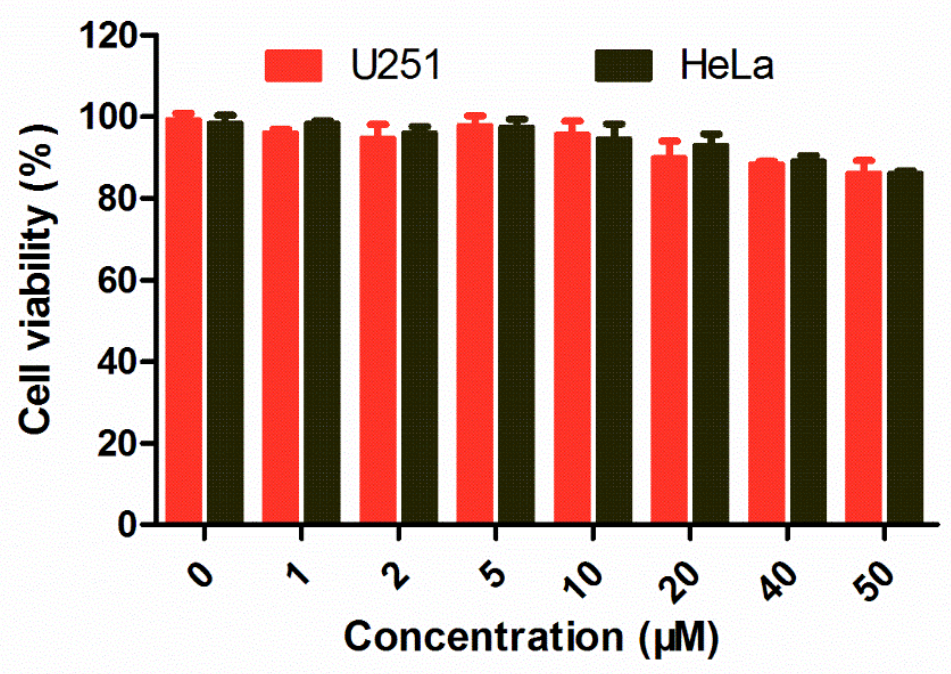

Figure S14. Viability of HeLa and U251 cells treated with various concentrations $(0-50 \mu \mathrm{M})$ of $\mathbf{C a P}$ for $24 \mathrm{~h}$. Error bars represent mean values \pm SD. $(n=3)$

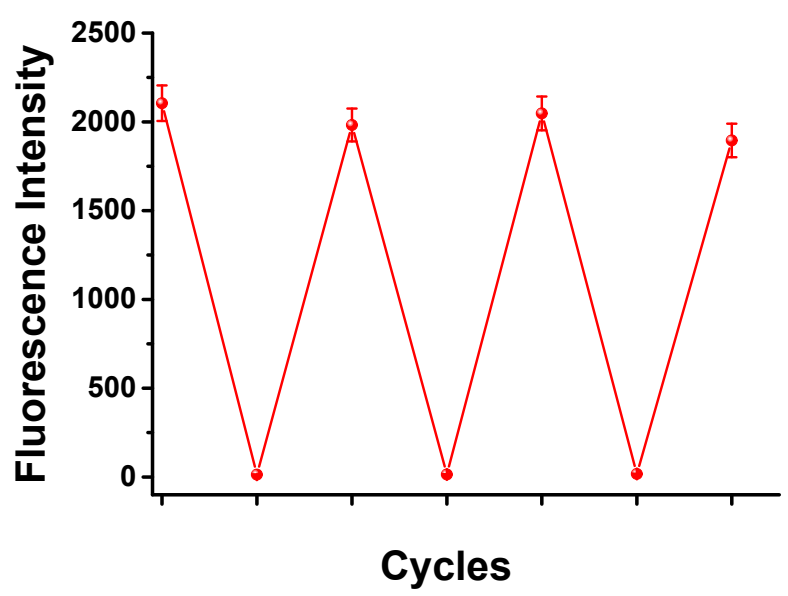

Figure S15. Quantification of fluorescence intensity of reversible cycling of $\mathbf{C a P}$ by addition of exogenous $\mathrm{SO}_{2}$ and FA. Error bars represent mean values $\pm \operatorname{SD}(n=3)$ 


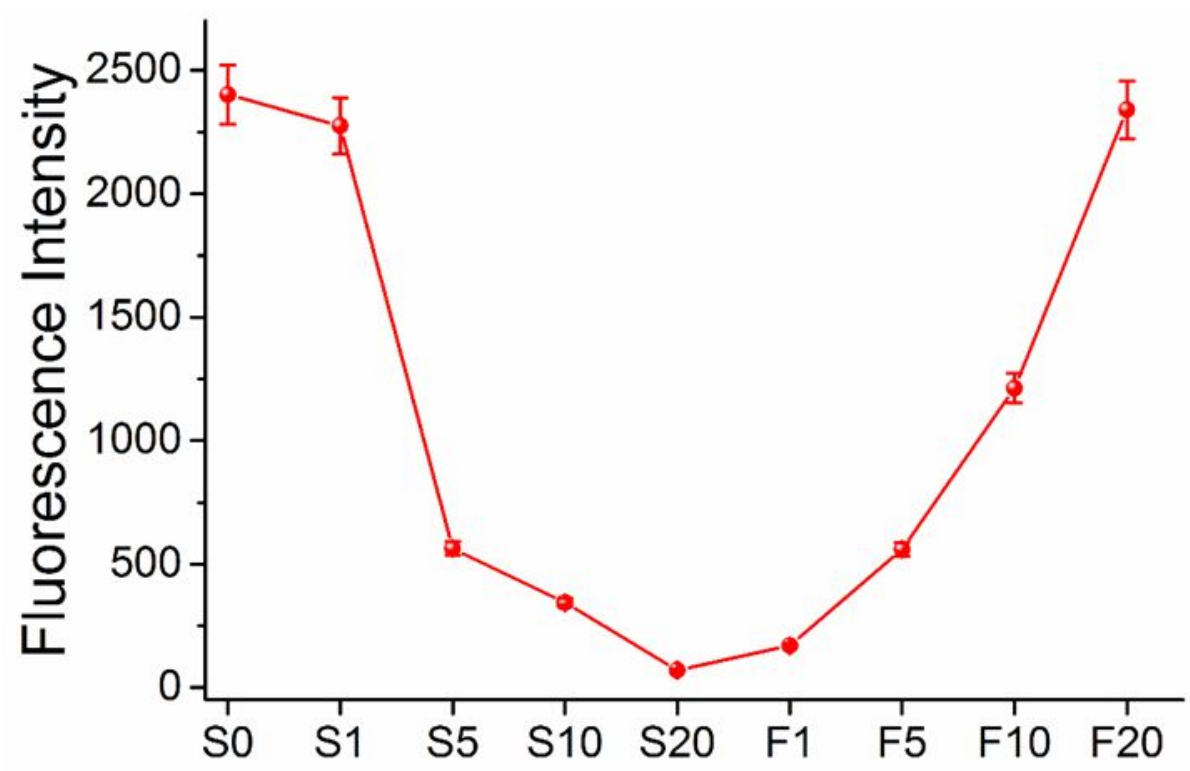

Figure S16. Quantification of fluorescence intensity of real-time imaging the dynamic changes of exogenous $\mathrm{SO}_{2}$ and $\mathrm{FA}$. Error bars represent mean values $\pm \mathrm{SD}(\mathrm{n}=3)$.

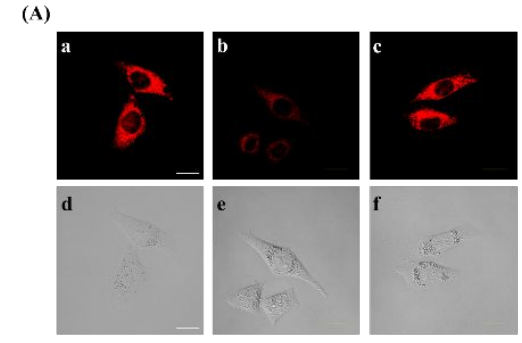

g

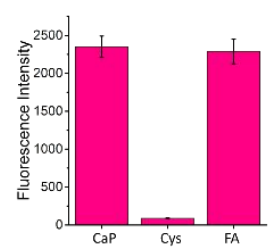

(B)
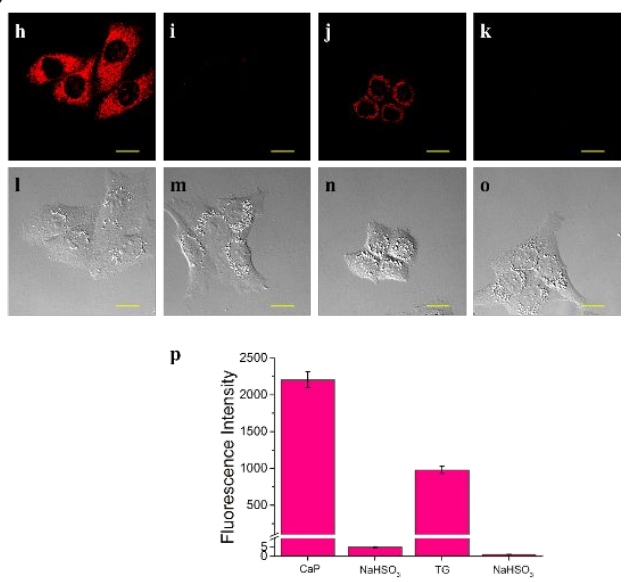

Figure S17. (A) Fluorescence images of $\mathbf{C a P}$ for detecting endogenous $\mathrm{SO}_{2}$ in living cells. a, The HeLa cells treated only with $10 \mu \mathrm{M}$ CaP. b. The HeLa cells pretreated with $10 \mu \mathrm{M}$ CaP followed by $200 \mu \mathrm{M}$ Cys. c, HeLa cells pretreated with 10 $\mu \mathrm{M}$ CaP followed by addition $200 \mu \mathrm{M}$ Cys, and then incubated with $400 \mu \mathrm{M}$ FA. d-f, The bright-field of a-c. g, Quantification of fluorescence intensity in HeLa cells (a-c). (B) Fluorescence images of CaP for tracking endogenous FA in living cells. h, The HeLa cells treated only with $10 \mu \mathrm{M} \mathrm{CaP}$. i, The HeLa cells pretreated with $100 \mu \mathrm{M} \mathrm{NaHSO}$ followed by $10 \mu \mathrm{M} \mathrm{CaP}$. j, The HeLa cells pretreated with $100 \mu \mathrm{M} \mathrm{NaHSO}_{3}$ followed by addition $20 \mu \mathrm{M}$ TG, then incubated with 10 $\mu \mathrm{M} \mathrm{CaP} . \mathbf{k}, 200 \mu \mathrm{M} \mathrm{NaHSO}{ }_{3}$ was further introduced to the above stained cells. l-o, The bright-field of h-k. p, Quantification of fluorescence intensity in HeLa cells (h-k). Red channel: $\lambda_{\mathrm{ex}}=561 \mathrm{~nm}, \lambda_{\mathrm{em}}=570-620 \mathrm{~nm}$. Scale bar: $20 \mu \mathrm{m}$.

\section{Characterization of all compounds}



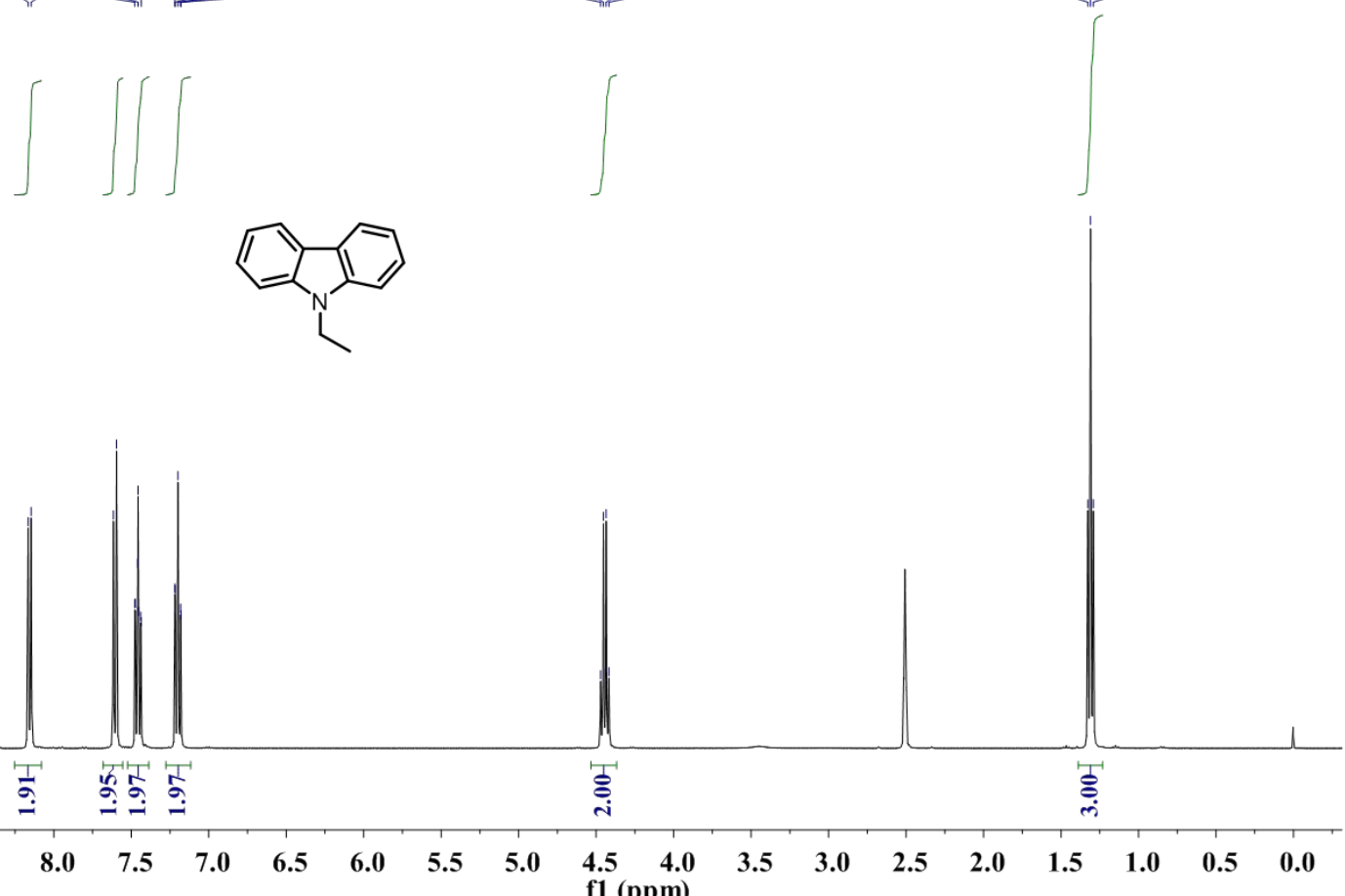

Figure S18. ${ }^{1} \mathrm{H}$ NMR spectrum of Compound 1 in DMSO-d ${ }_{6}$.

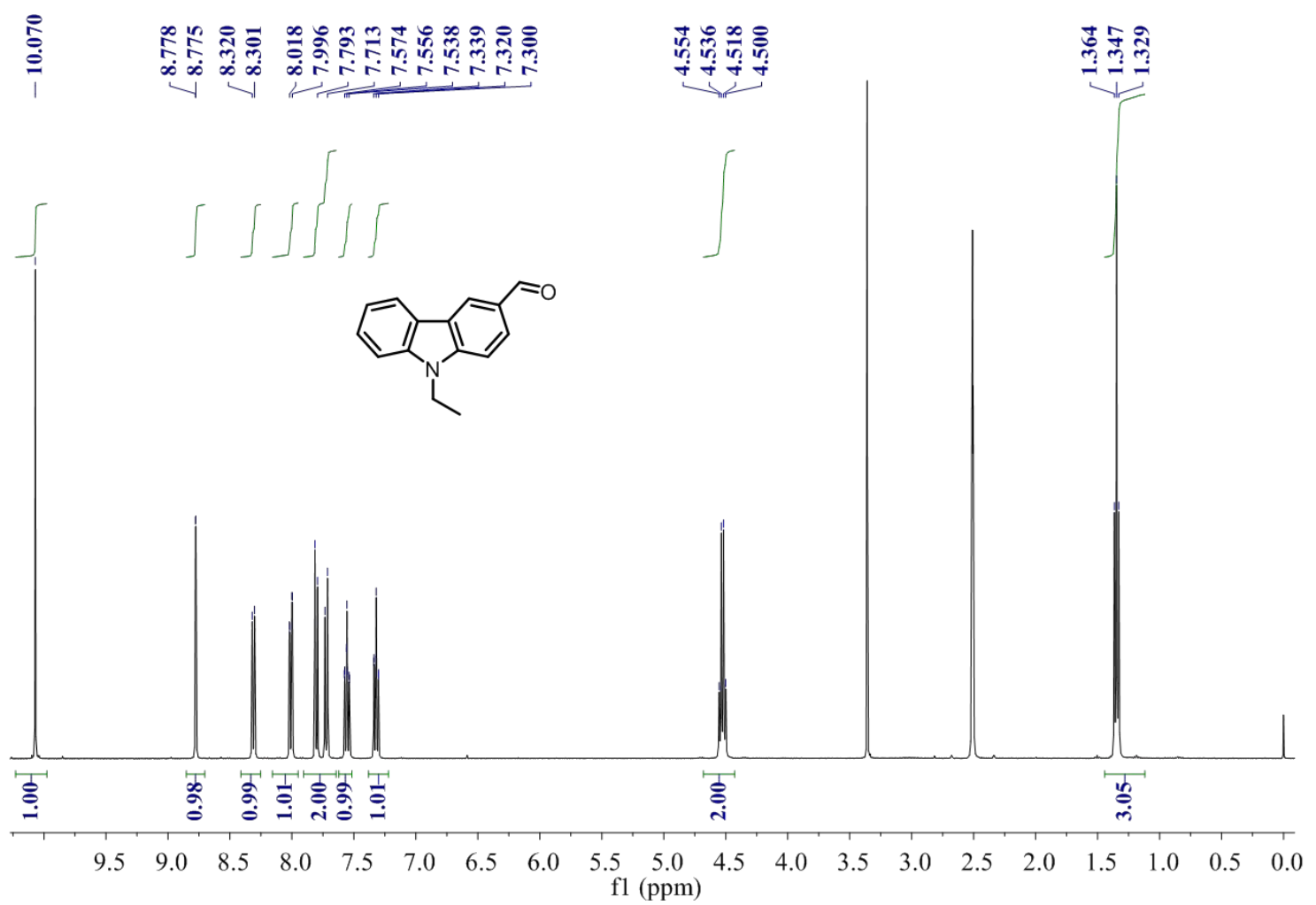

Figure S19. ${ }^{1} \mathrm{H}$ NMR spectrum of Compound 2 in DMSO- $\mathrm{d}_{6}$. 

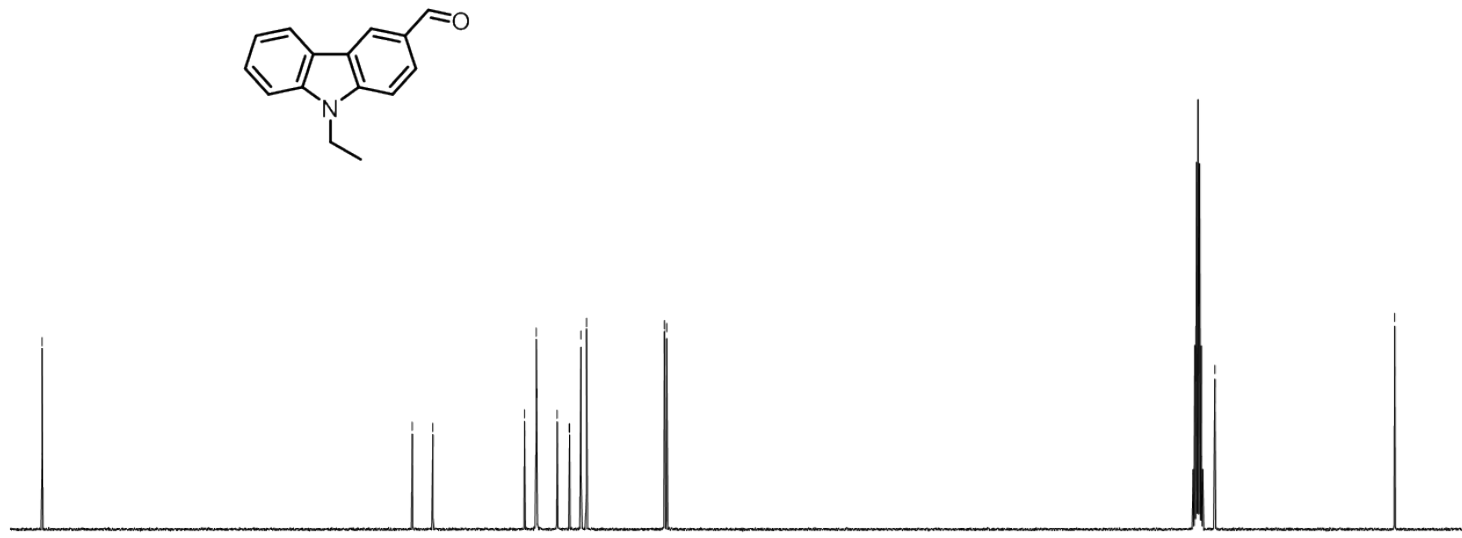

$\begin{array}{lllllllllllllllllll}190 & 180 & 170 & 160 & 150 & 140 & 130 & 120 & 110 & 100 & 90 & 80 & 70 & 60 & 50 & 40 & 30 & 20 & 10\end{array}$

Figure S20. ${ }^{13} \mathrm{C}$ NMR spectrum of Compound 2 in DMSO- $\mathrm{d}_{6}$.

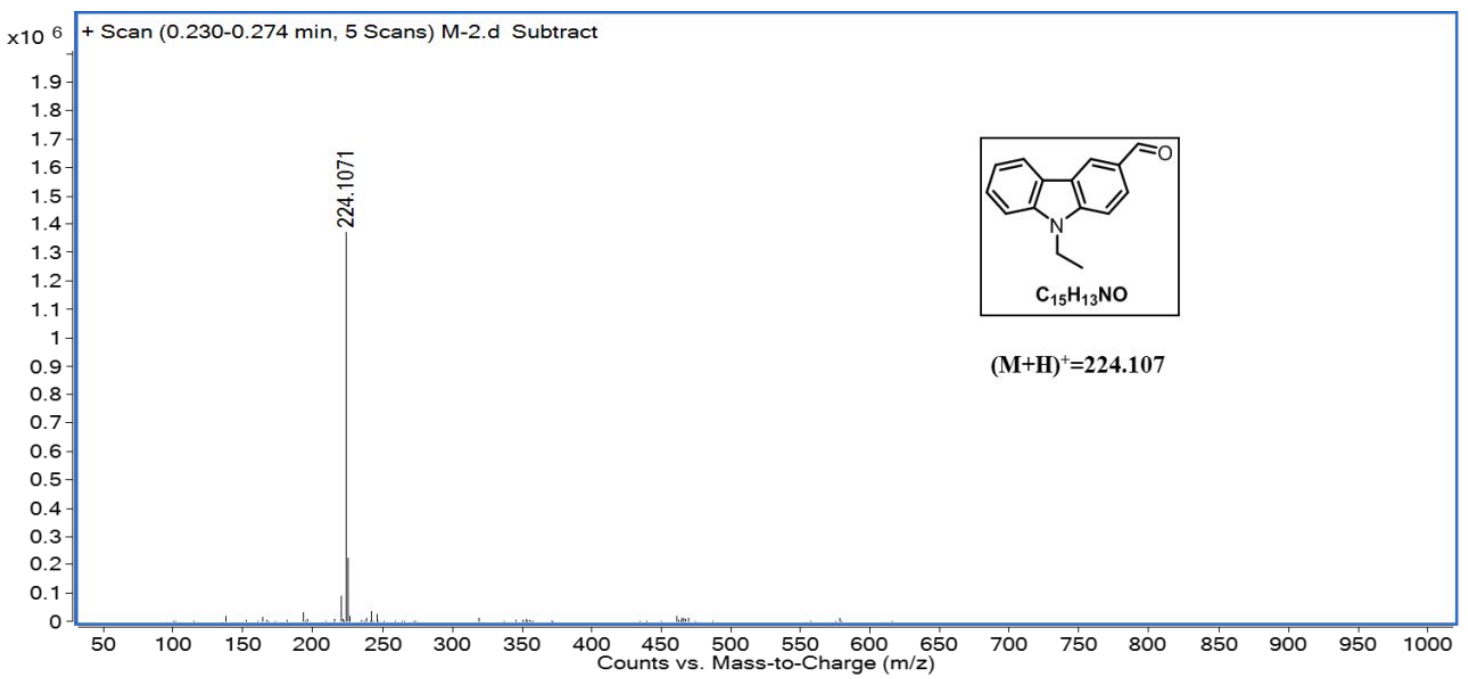

Figure S21. HR-MS spectrum of Compound 2. 


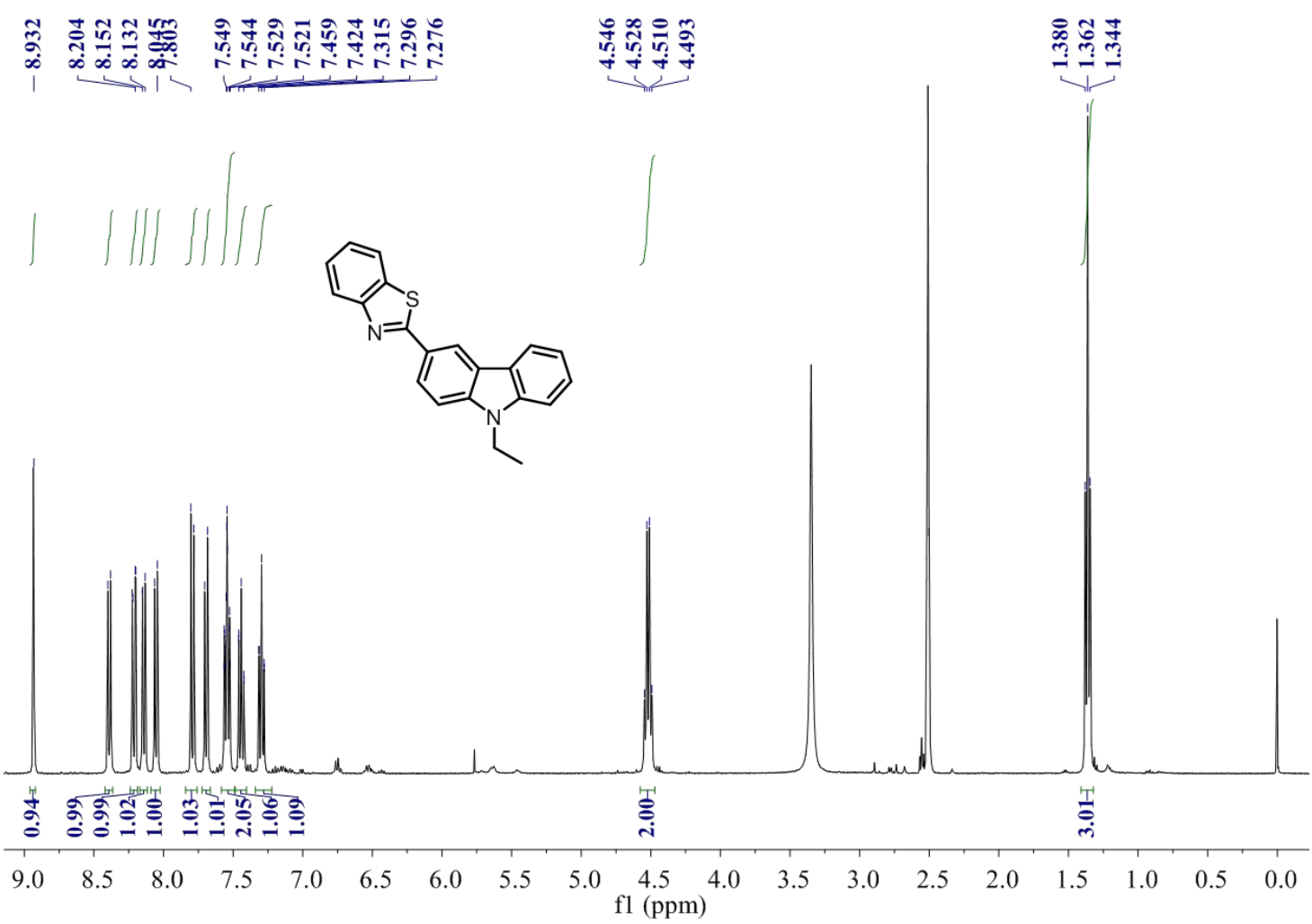

Figure S22. ${ }^{1} \mathrm{H}$ NMR spectrum of Compound 3 in DMSO- $\mathrm{d}_{6}$.

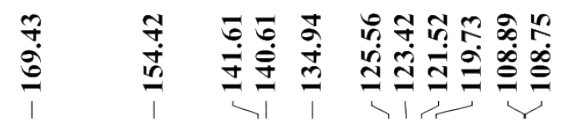
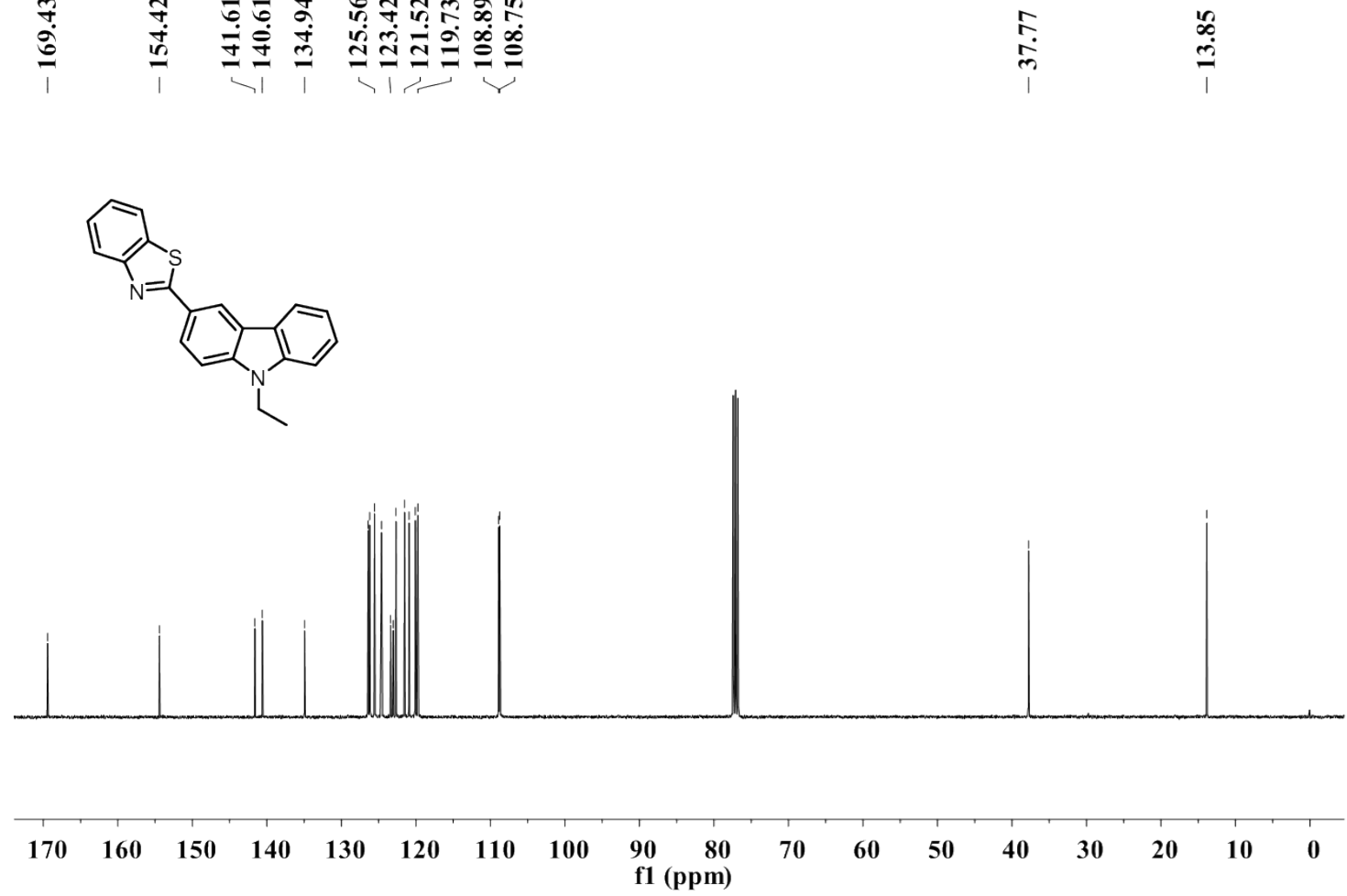

Figure S23. ${ }^{13} \mathrm{C}$ NMR spectrum of Compound $\mathbf{3}$ in $\mathrm{CDCl}_{3}$. 


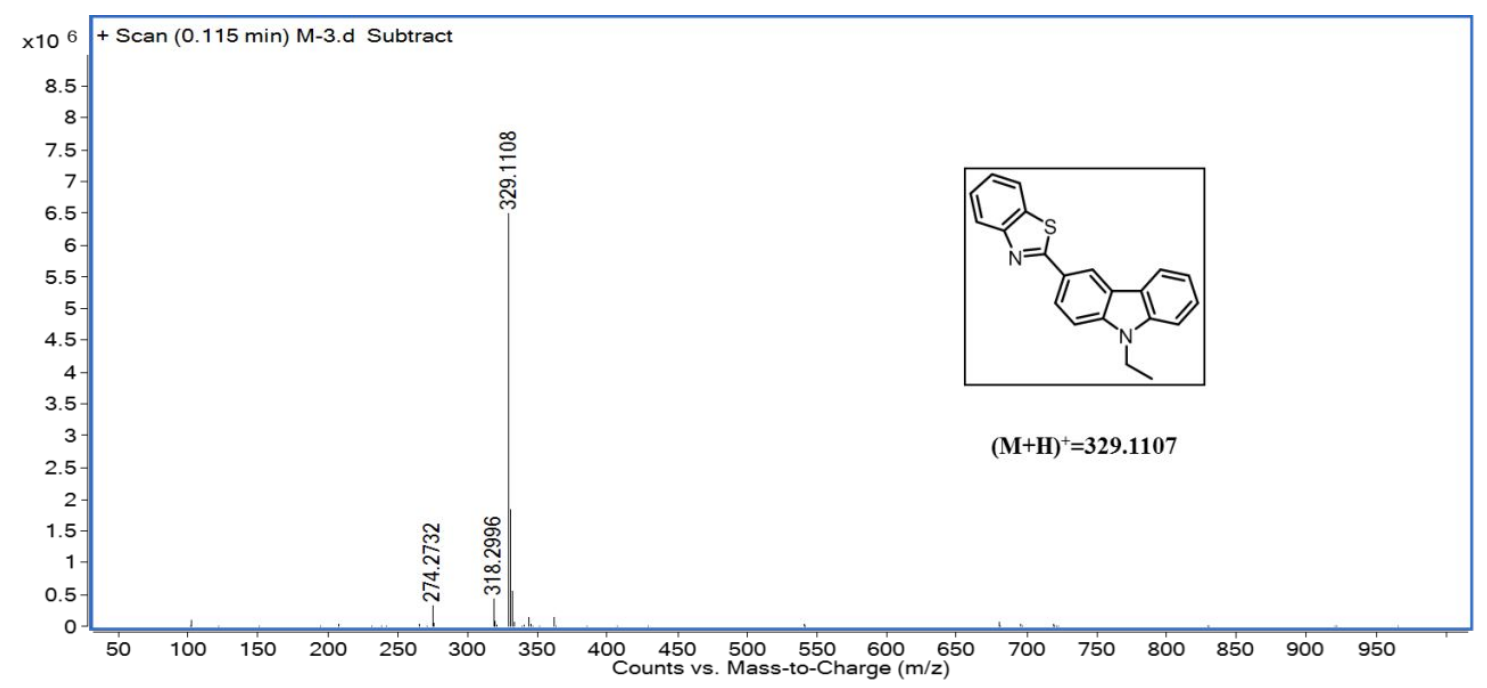

Figure S24. HR-MS spectrum of Compound 3.

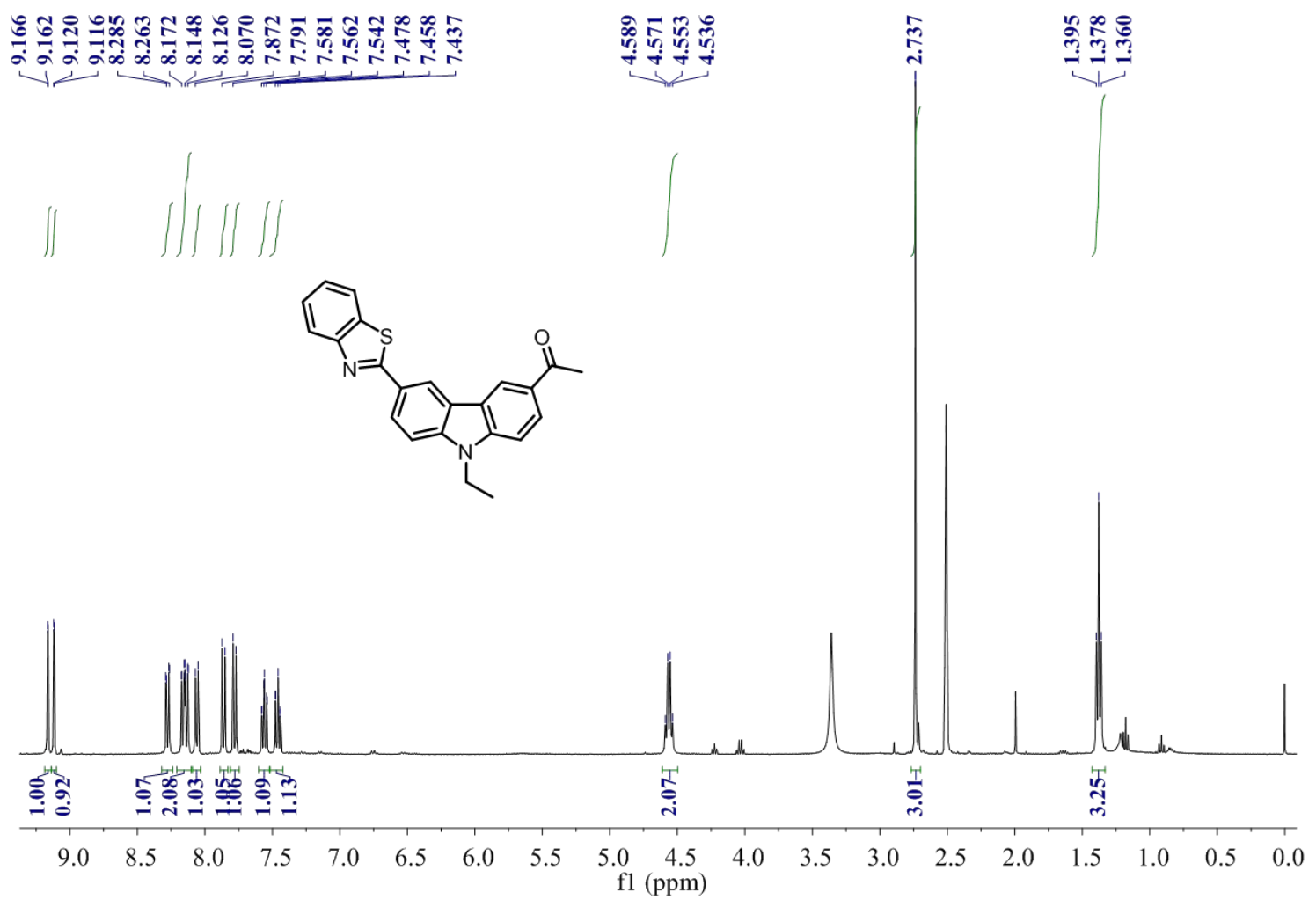

Figure S25. ${ }^{1} \mathrm{H}$ NMR spectrum of Compound 4 in DMSO- $\mathrm{d}_{6}$. 

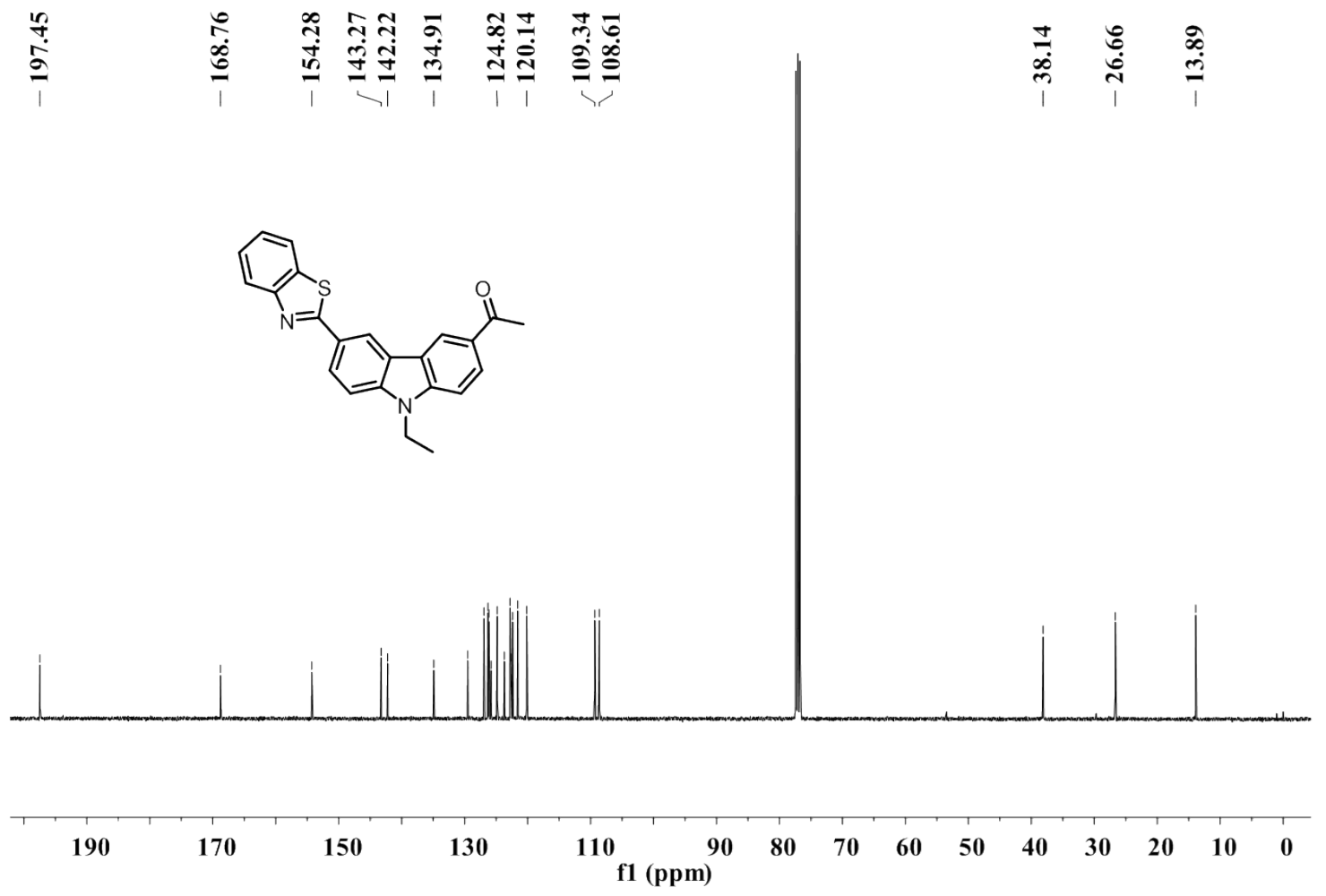

Figure S26. ${ }^{13} \mathrm{C}$ NMR spectrum of Compound 4 in $\mathrm{CDCl}_{3}$.

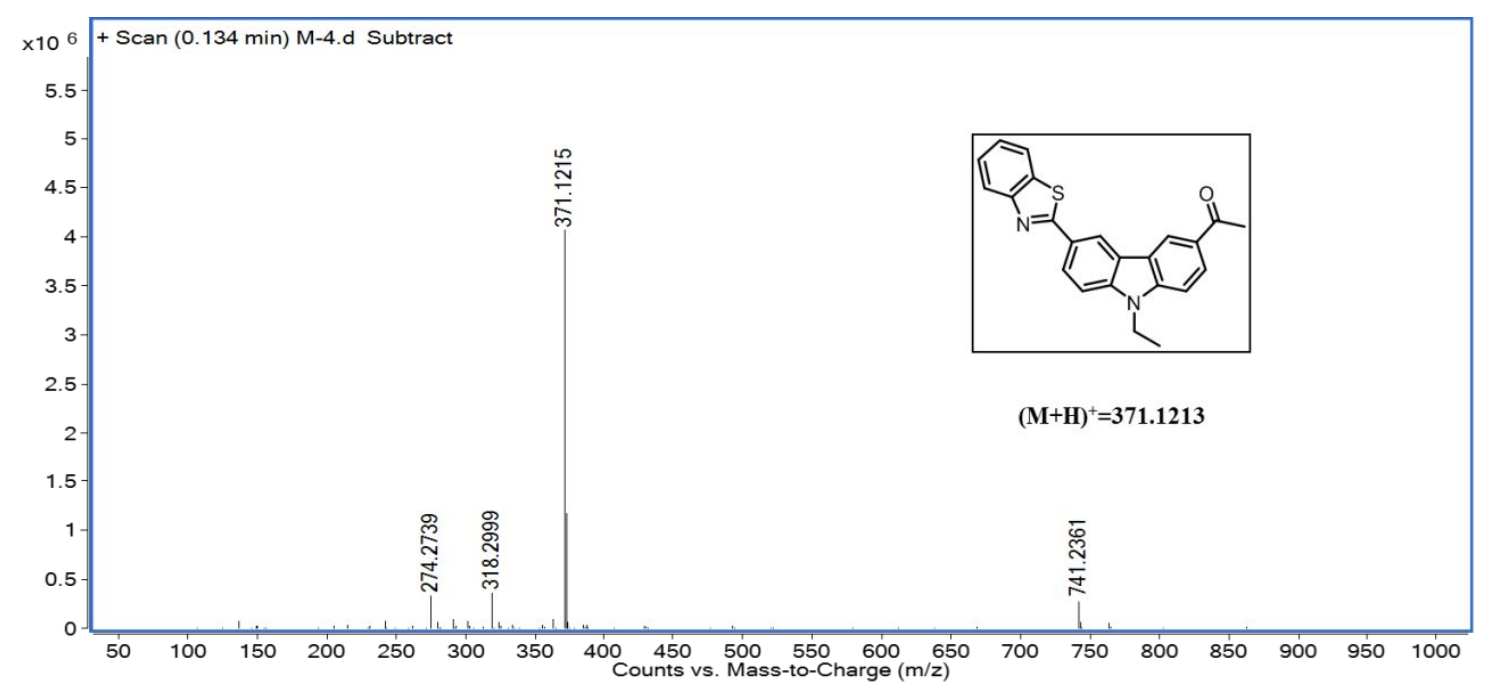

Figure S27. HR-MS spectrum of Compound 4. 


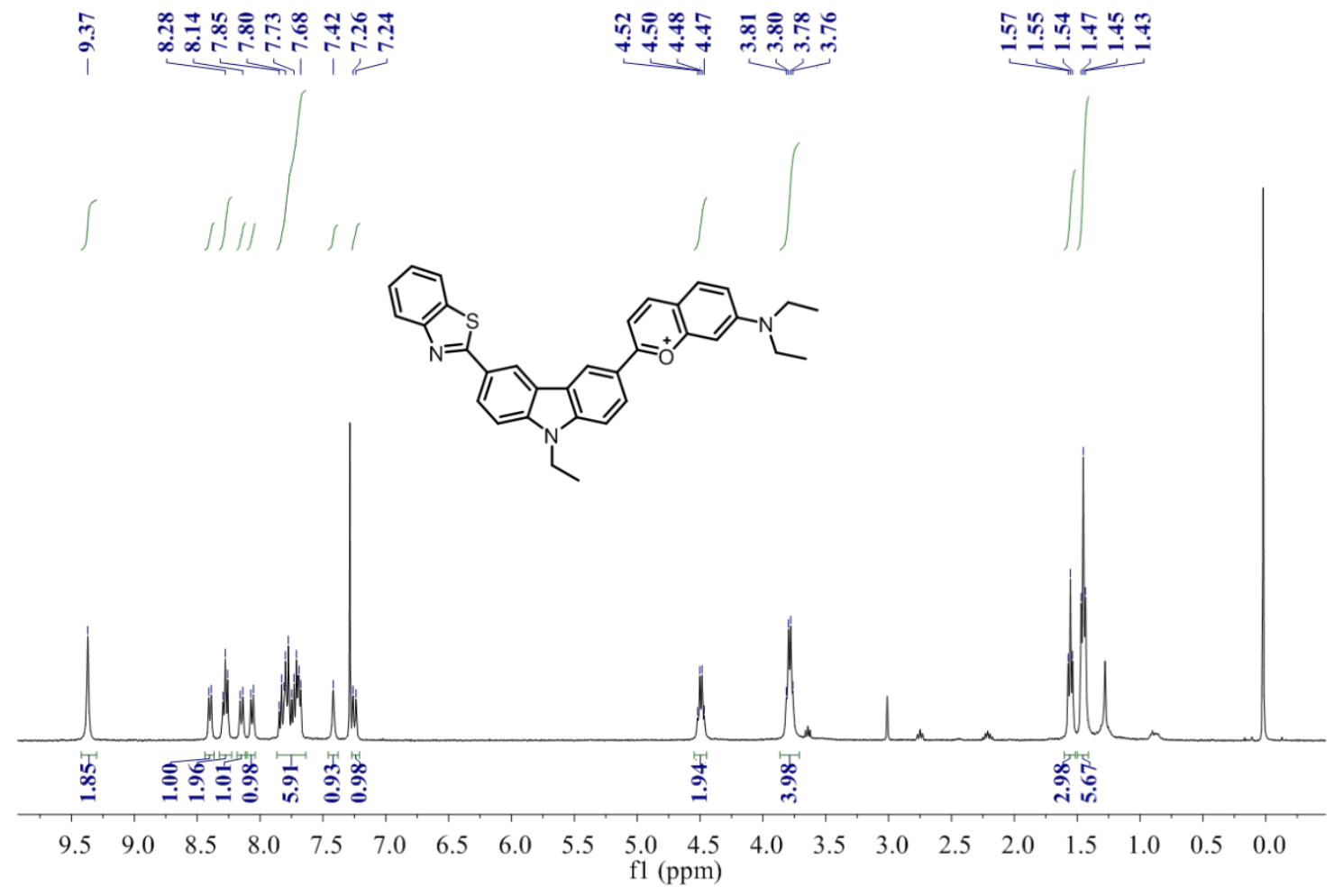

Figure S28. ${ }^{1} \mathrm{H}$ NMR spectrum of TCaP in $\mathrm{CDCl}_{3}$ (with $5 \%$ deuterium trifluoroacetic acid (V/V) to increase the solubility).

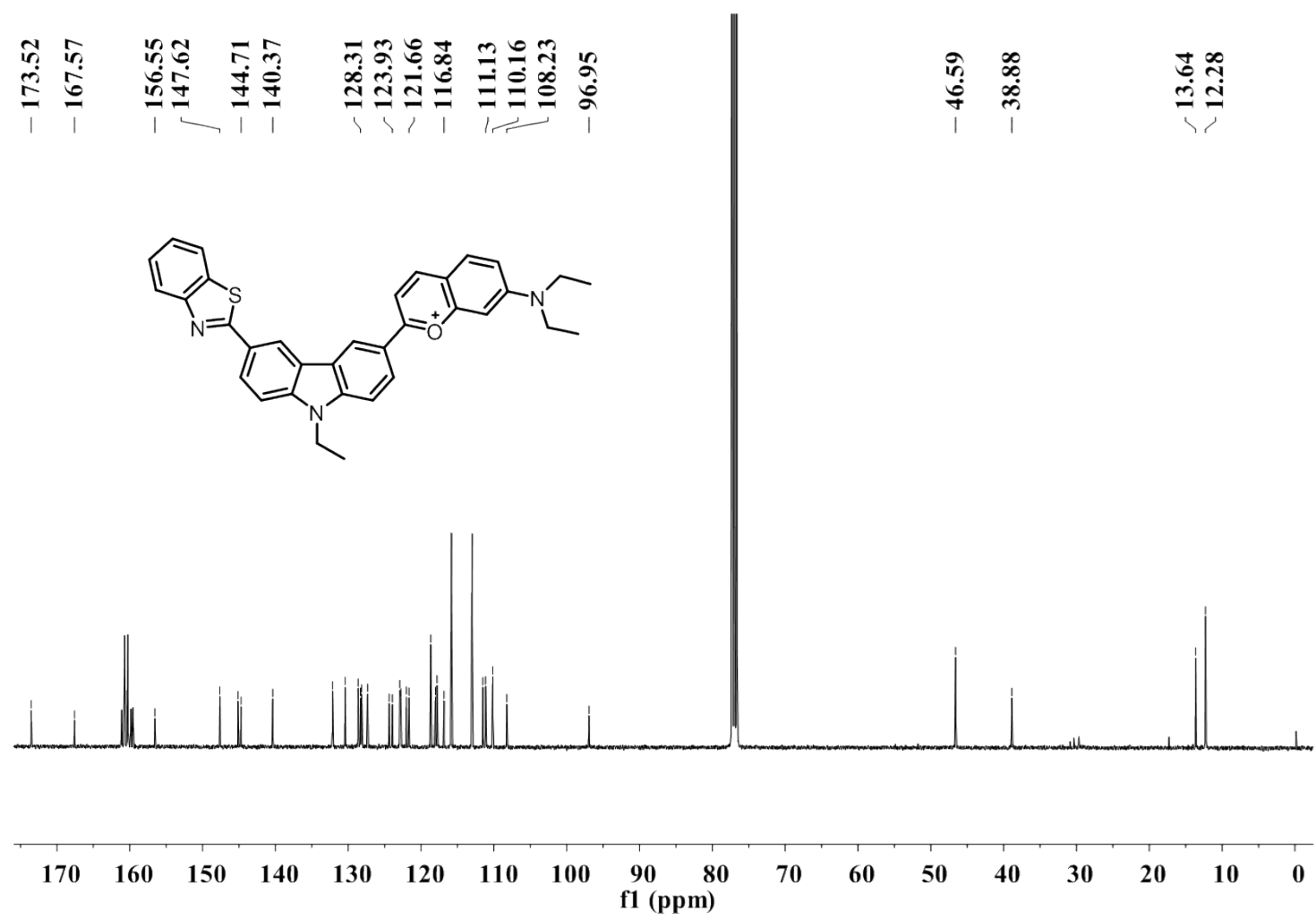

Figure S29. ${ }^{13} \mathrm{C}$ NMR spectra of $\mathbf{T C a P}$ in $\mathrm{CDCl}_{3}$ (with $5 \%$ deuterium trifluoroacetic acid (V/V) to increase the solubility)DMSO- $d_{6}$. 


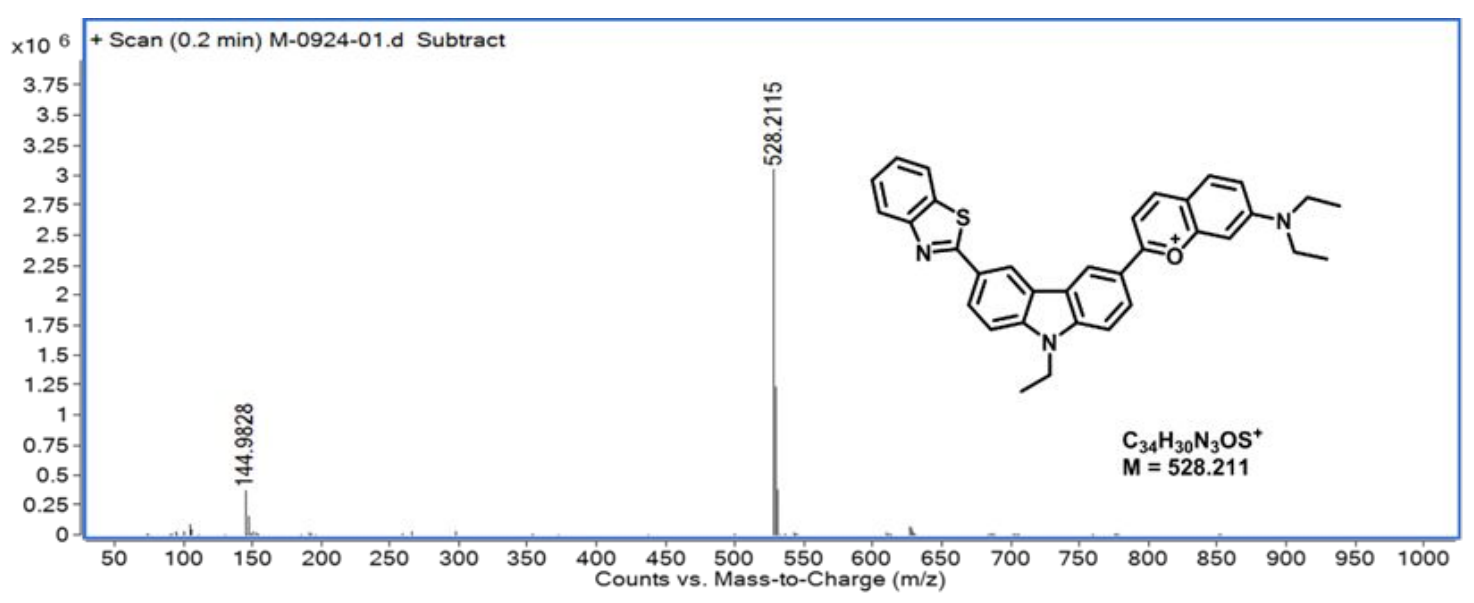

Figure S30. HR-MS spectrum of TCaP.

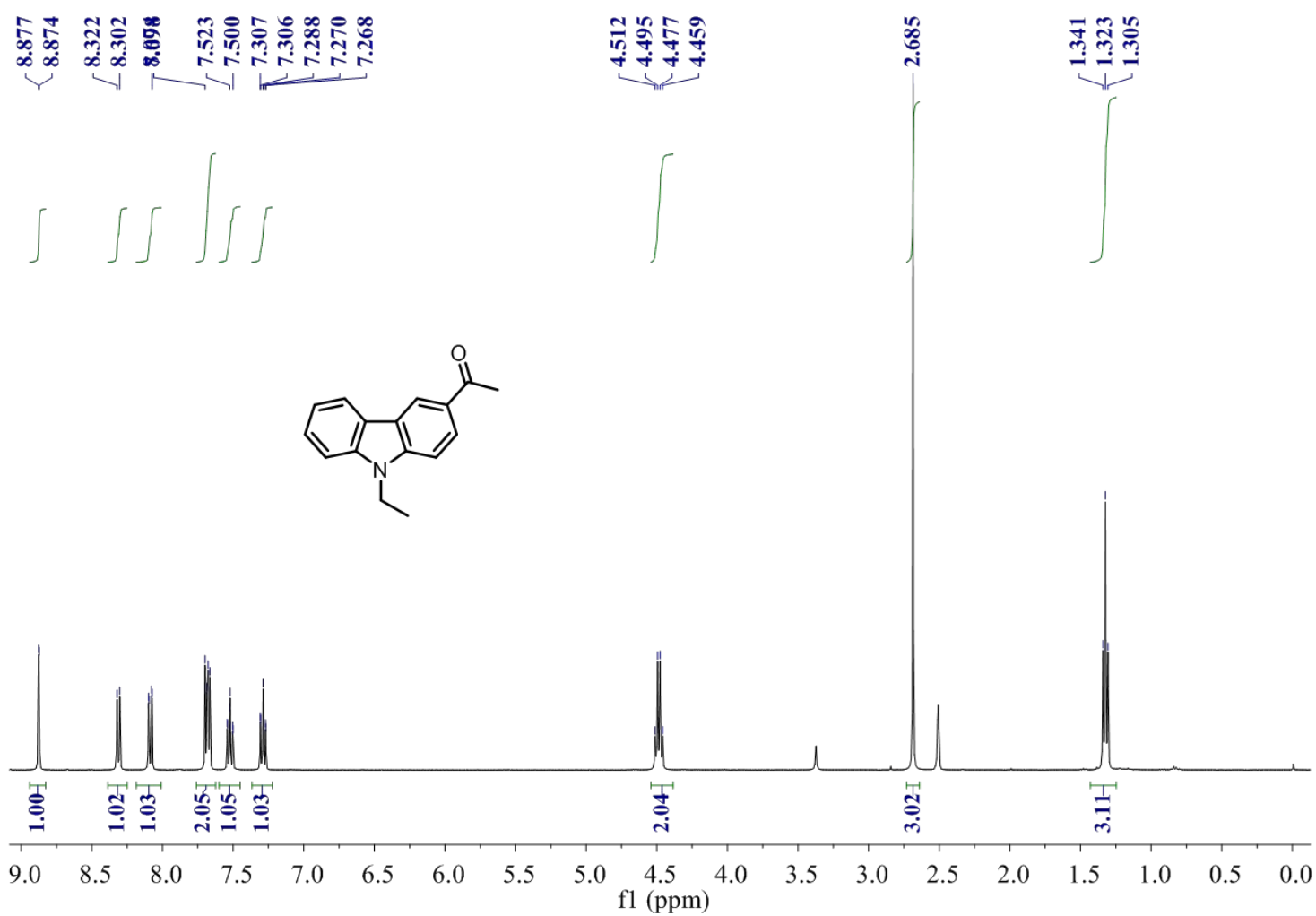

Figure S31. ${ }^{1} \mathrm{H}$ NMR spectrum of Compound 5 in DMSO- $\mathrm{d}_{6}$. 


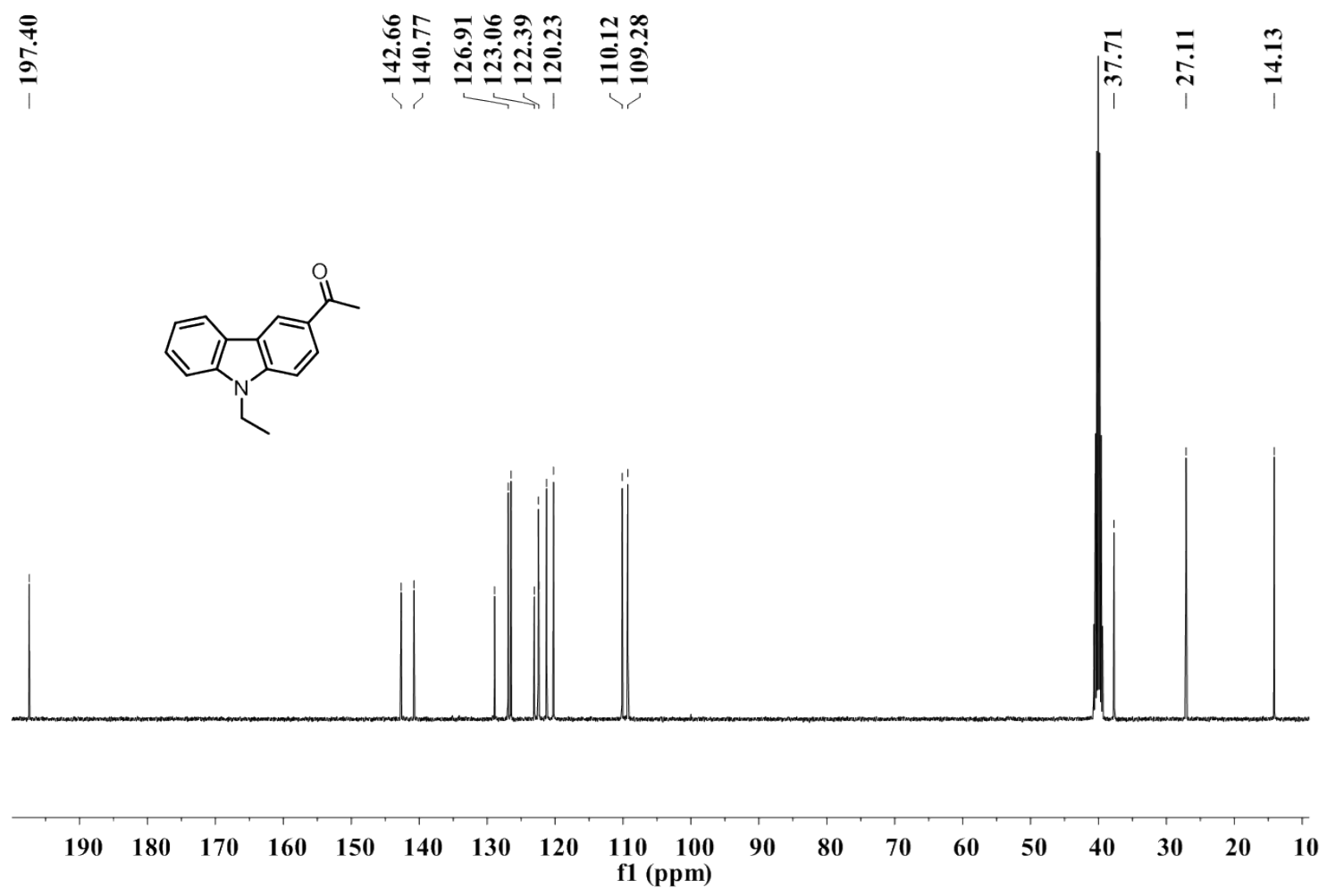

Figure S32. ${ }^{13} \mathrm{C}$ NMR spectrum of Compound 5 in DMSO- $\mathrm{d}_{6}$.

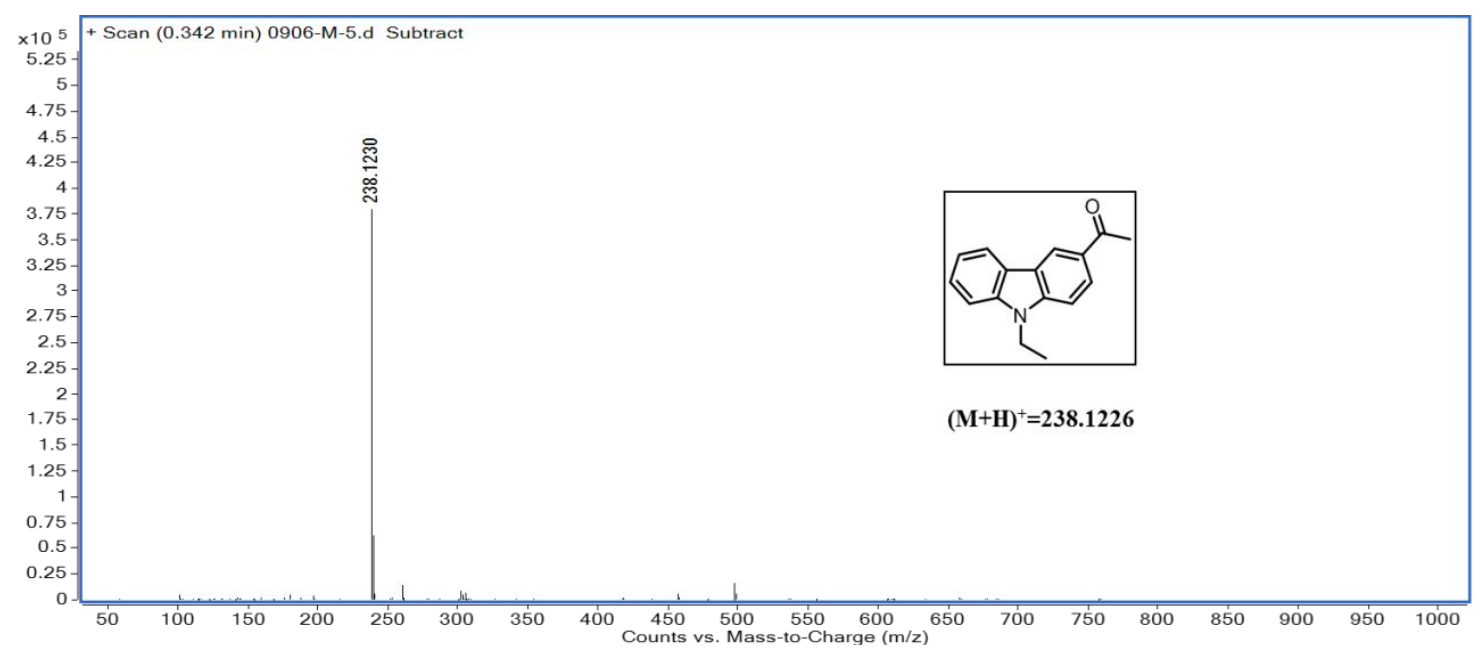

Figure S33. HR-MS spectrum of Compound 5. 


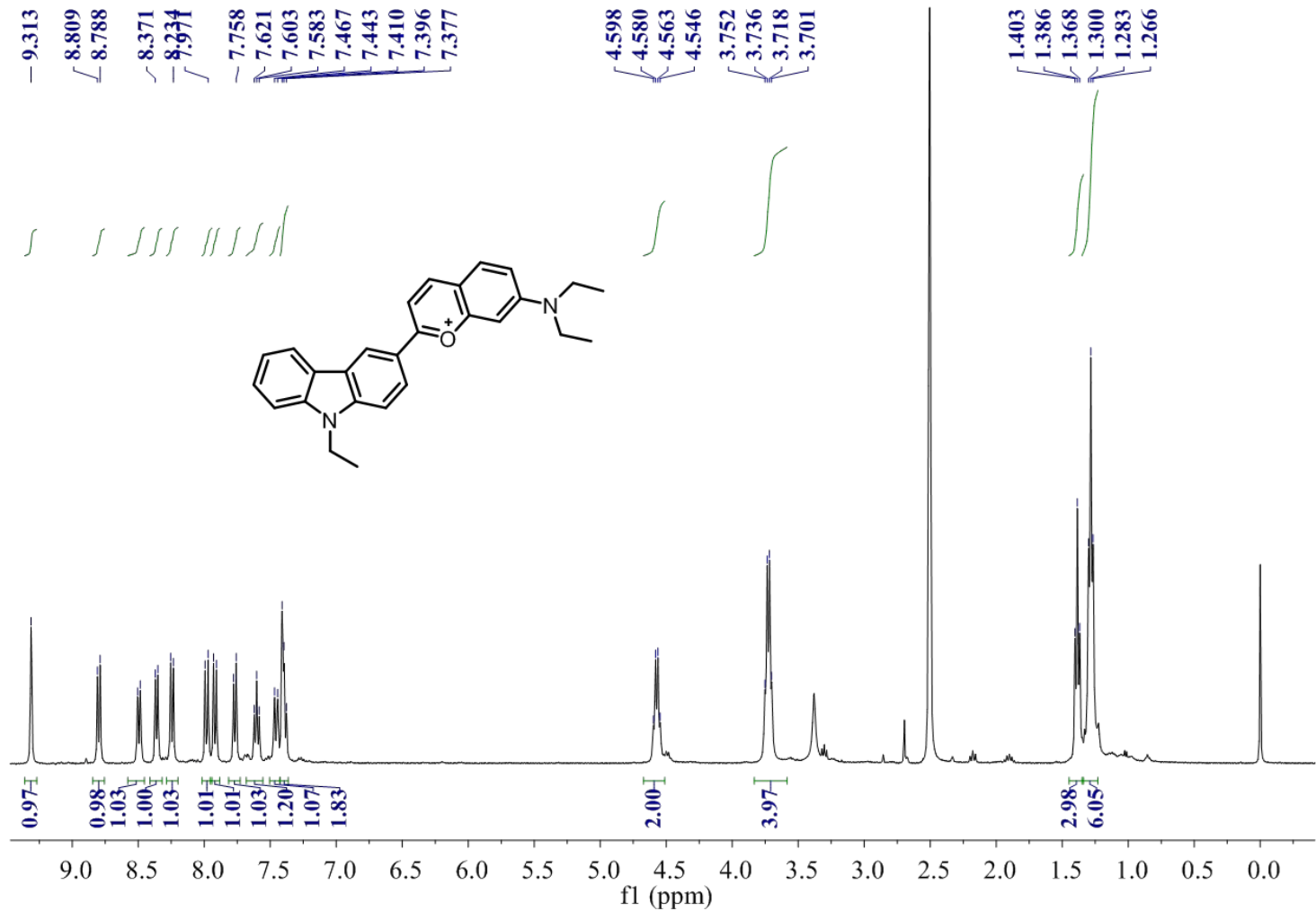

Figure S34. ${ }^{1} \mathrm{H}$ NMR spectrum of CaP in DMSO- $\mathrm{d}_{6}$.
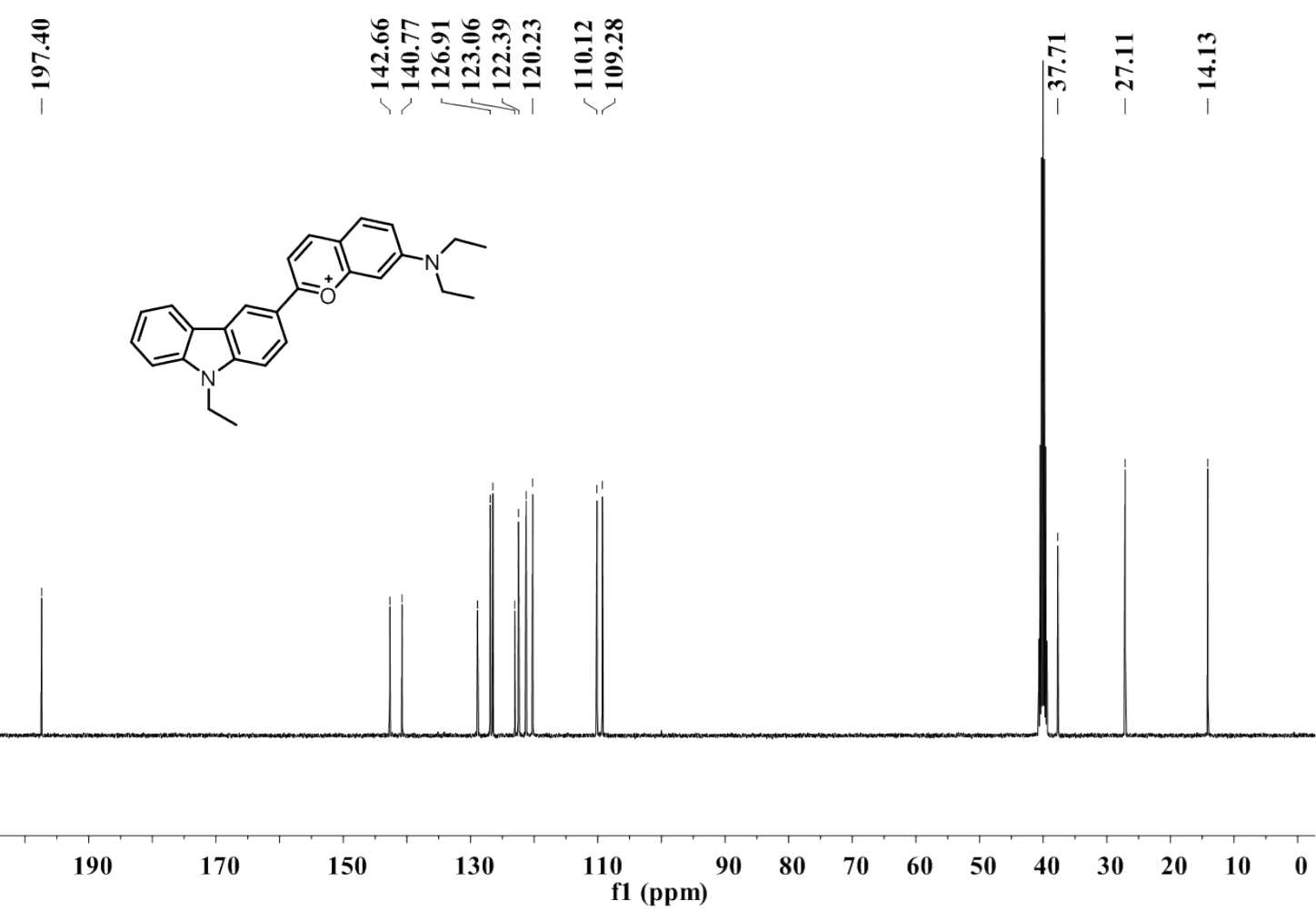

Figure S35. ${ }^{13} \mathrm{C}$ NMR spectrum of CaP in DMSO- $\mathrm{d}_{6}$. 


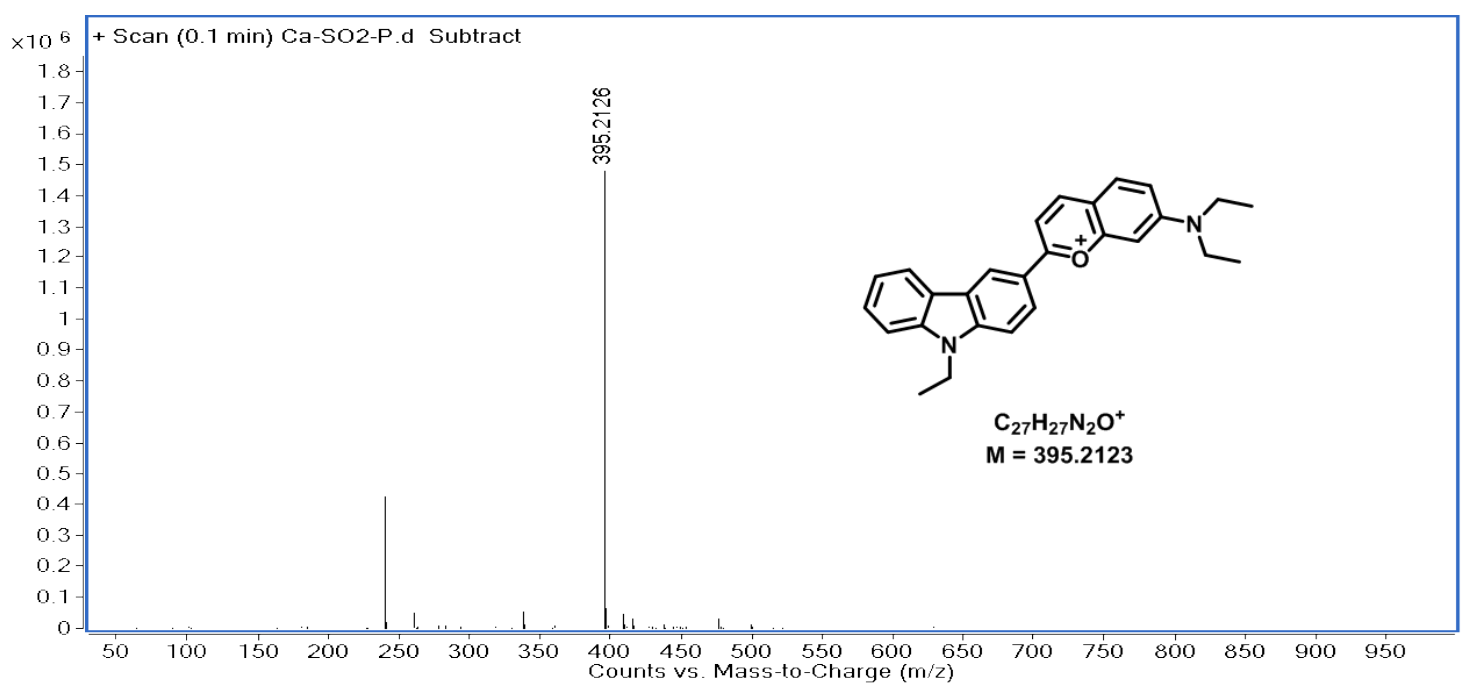

Figure S36. HR-MS spectrum of CaP.

\section{Supplementary References}

[1] M. Shortreed, R. Kopelman, M. Kuhn, B. Hoyland, Anal. Chem. 1996, 68, 1414-1418.

\section{Supplementary Videos}

Supplementary Video S1: Naked-eye confirmation (in terms of color change) of reversible detection of $\mathrm{SO}_{2}$ and $\mathrm{FA}$ by $\mathbf{C a P}$ $(10 \mu \mathrm{M}) . \mathrm{NaHSO}_{3}$ and FA with mole ratio of 1:4 were added alternately. Solvent: HEPES buffer, pH 7.0, containing 20\% $\mathrm{CH}_{3} \mathrm{CN}$. 